\title{
Perfiles jurisprudenciales de la protección a los terceros adquirentes de viviendas mediante compraventa en Cuba
}

Jurisprudential profiles of the protection of third party purchasers of real estate in Cuba

\author{
Suset Hernández Guzmán ${ }^{1}$ \\ Universidad de La Habana, Cuba
}

Revista Derechos en Acción ISSN 2525-1678/ e-ISSN 2525-1686

Año 6/Nº 19 Otoño 2021 (21 marzo a 20 junio), 439-483

DOl: https://doi.org/10.24215/25251678e523

Recibido: 01/01/2021

Aprobado: 15/03/2021

Resumen: El artículo muestra un acercamiento a la realidad cubana en torno a la protección a los terceros adquirentes de viviendas obtenidas mediante contrato de compraventa entre personas naturales, en atención a las sentencias dictadas por el Tribunal Supremo Popular con posterioridad a 2011. Las severas limitaciones impuestas a la autonomía privada en relación con este contrato en particular desde los primeros años de la Revolución, unido al sensible desmantelamiento del Registro de la Propiedad regido por la Ley Hipotecaria de 1893, determinan la desaparición de estos sujetos del escenario jurídico hasta que se produce la flexibilización del tráfico inmobiliario del país en el año indicado, con la

\footnotetext{
1 Licenciada en Derecho por la Universidad de La Habana (2009). Profesora Auxiliar del Departamento de Derecho Civil y de Familia de la Facultad de Derecho de este centro de altos estudios (2018). Máster en Derecho Civil por la propia institución (2016). Aspirante a Doctora en Ciencias Jurídicas y Empresariales por la Universidad de Almería, España y por la Universidad de La Habana, Cuba; en razón del Convenio de Cotutela Internacional para Tesis de Doctorado. Ex jueza suplente no permanente de lo Civil y lo Familiar del Tribunal Provincial de La Habana. Notaria en ejercicio. Email: suset@lex.uh.cu (ORCID: https://orcid. org/0000-0001-8802-4346)..
} 
puesta en vigor del Decreto Ley Núm. 288, modificativo de la Ley General de la Vivienda. Por ello, se valoran las soluciones ofrecidas por la máxima judicatura cubana a fin de identificar un posible perfil jurisprudencial de los terceros adquirentes y proponer pautas de actuación jurisdiccional que guíen el camino hacia su efectiva protección en el corto plazo.

Palabras claves: Tercero adquirente, compraventa de vivienda, tutela jurisdiccional, aplicación del Derecho.

Abstract: The article shows an approach of the protection of real estate
third party purchasers by sale between natural persons in Cuba, in response
to the judgments issued by the Supreme People's Court after 2011. Severe
limitations imposed on private autonomy, regarding to this contract from the
early years of the Revolution, together with the sensitive dismantling of
the Property Registry governed by the Land Register and Mortgage Law of 1893,
determined the disappearance of these subjects from the national legal
scene until 2011, when the country's real estate traffic became more
flexible, through the enactment of Decree Law No. 288 that amended
the General Housing Law. Due to this reason, the solutions offered by the
highest Cuban judiciary are valued in order to identify a possible jurispru-
dential profile of third-party acquirers and to propose guidelines for judicial
action that set the way towards their effective protection in the short term.

Keywords: Third party acquirer on real estate, dwellings sales, judicial protection, Law application.

\section{El contexto que trasciende a la impartición de justicia. A modo de introducción}

La protección a los terceros adquirentes de inmuebles, en particular, de viviendas de residencia permanente adquiridas mediante contrato de compraventa entre particulares, constituye un tema de máxima actualidad en el contexto cubano. La asentada tutela jurisdiccional a favor de estos sujetos se frustra a partir de la segunda mitad de la década de los sesenta del siglo $\mathrm{XX}^{2}$,

2 La aprobación y entrada en vigor de la Ley de Reforma Urbana (LRU) en 1960, primero, y luego de la Ley Núm. 1180 en 1965, incide de manera directa en la decadencia del Registro 
tras la desarticulación del Registro de la Propiedad en Cuba, fundado en 1880 y regido por la Ley Hipotecaria para las Provincias de Ultramar (LHU) de $1893^{3}$. La sensible disminución del tráfico jurídico de este tipo de inmuebles también influye en la distorsión de la figura en estudio; pues la compraventa de viviendas recibe -desde los primeros años revolucionariosserias limitaciones legales que afectan la autonomía de la voluntad y reducen el contenido esencial del derecho de propiedad procurado a través de esta modalidad contractual, casi a su mínima expresión ${ }^{4}$.

Así, el desmantelamiento del Registro de la Propiedad que constituye pilar inexorable de la protección a los terceros adquirentes de inmuebles, unido a la imposibilidad de trasmitir libremente las viviendas mediante compraventa, determinan que el artículo 34 de la $\mathrm{LHU}^{5}$, amparador de la fe pública registral y, por tanto, el principal fundamento legal que hasta aquel

de la Propiedad como medio de aseguramiento de los derechos reales en el país, al punto de pasar desapercibido por la palestra jurídica cubana por casi cuarenta años. Ley de Reforma Urbana, de 14 de octubre de 1960, publicada en la Gaceta Oficial de la República de Cuba, edición Extraordinaria, en la propia fecha de su promulgación, en Leyes del Gobierno Provisional de la Revolución, Folletos de Divulgación Legislativa, Núm. XXV $\left(1^{\circ}\right.$ al 31 de octubre de 1960), Ed. Lex, La Habana, 1960, pp. 5-33. Publicada en la Gaceta Oficial de la República de Cuba, Núm. 11, edición Ordinaria, de 5 de julio de 1965, en Leyes del Gobierno Revolucionario de Cuba Provisional, Folletos de Divulgación Legislativa, Núm. LVIII (julio, agosto y septiembre de 1965), Ed. Nacional de Cuba, La Habana, 1965, pp. 5-18.

3 Ley de 14 de julio de 1893, en edición oficial promovida por el Ministerio de Ultramar, Ed. Imprenta de la viuda de M. Minuesa de los Ríos, Madrid, 1893.

4 La LRU, unido a las leyes generales de la vivienda que emergieron en la década de los ochenta del siglo XX, provocan prácticamente la prohibición de celebrar este contrato entre personas naturales, ya que desde un inicio el Estado se arroga el derecho de tanteo sobre cualquier venta que desearan efectuar los particulares, y luego, solo a través de él, es que las personas podrían comprar estos inmuebles mediante compraventa. Ley Núm. 48, Ley General de la Vivienda ( $1^{\mathrm{a}}$ LGV) de 27 de diciembre de 1984, publicada en la Gaceta Oficial de la República de Cuba, Núm. 22, edición Extraordinaria, de 31 de diciembre de 1984. Ley Núm. 65, Ley General de la Vivienda (2a LGV) de 23 de diciembre de 1988, publicada en la Gaceta Oficial de la República de Cuba, Núm. 3, edición Extraordinaria, de 8 de febrero de 1989.

5 Artículo 34: (...) los actos o contratos que se ejecuten u otorguen por persona que en el Registro aparezca con derecho para ello, no se invalidarán en cuanto a tercero, una vez 
momento mantiene a salvo las adquisiciones experimentadas por terceros adquirentes de buena fe y a título oneroso en la Isla, inicie un largo período de inaplicación ${ }^{6}$. Por ello, la hipótesis normativa contenida en el citado precepto deja de tener virtualidad jurídica, en tanto las condiciones objetivas no favorecen la configuración de los terceros adquirentes ${ }^{7}$.

Con el Decreto Ley Núm. 288 de $2011^{8}$ se autoriza la celebración de contratos de compraventas de viviendas de residencia permanente entre particulares. Como resultado de la implementación del numeral 297 de los Lineamientos de la Política Económica y Social del Partido y la Revolución', la anhelada flexibilización del tráfico inmobiliario ve la luz y, en su razón, se

inscritos, aunque después se anule o resuelva el derecho del otorgante en virtud de título anterior no inscrito o de causas que no resulten claramente el mismo Registro.

6 En realidad, todo el andamiaje jurídico registral cae en desuso.

7 El tercero adquirente resulta ser quien, a partir de una relación jurídica obligacional válidamente establecida, obtiene el derecho de propiedad respecto a un bien inmueble de quien aparentemente está legitimado para transmitir (transferente o transmitente). Su titularidad real es cuestionada por el titular civil -conforme a la nomenclatura tradicional, el verus dominus-, como consecuencia de la declaración de invalidez o ineficacia del acto jurídico que antecede a su adquisición -que ataca directamente la titularidad de su transmitente en supuestos de conexión lineal- 0 al reconocimiento de un derecho preexistente -a favor del titular civil, en supuestos de conexión transversal ob rem-, desencadenantes de la ausencia o insuficiencia de facultad dispositiva en su transmitente. En otras palabras, se trata del sujeto que ha adquirido el derecho real por antonomasia de manos de un no propietario, experimentando una adquisición a non domino; pero lo ha hecho bajo la confianza que le infunde el Registro de la Propiedad, donde aparece el transferente como el legítimo titular real (titular registral).

8 Decreto Ley Núm. 288, Modificativo de la Ley No. 65, de 23 de diciembre de 1988, "Ley General de la Vivienda", de 28 de octubre de 2011, publicado en la Gaceta Oficial de la República de Cuba, Núm. 35, edición Extraordinaria, de 2 de noviembre de 2011, en vigor desde el 10 de noviembre del propio año.

9 Aprobados en el VI Congreso del Partido Comunista de Cuba, en el propio año 2011. Con el propósito de actualizar el modelo económico cubano se ordena, en el lineamiento 297: Establecer la compraventa de viviendas y flexibilizar otras formas de transmisión de la propiedad (permuta, donación y otras) entre personas naturales. Agilizar los trámites para la remodelación, rehabilitación, construcción, arrendamiento de viviendas y transferencia de propiedad, con el objetivo de facilitar la solución de las demandas habitacionales de la población. Cfr. VI Congreso del Partido Comunista de Cuba, Lineamientos de la Política Económica y Social del Partido y la Revolución, aprobado el 18 de abril del año 2011, p. 37, disponible en 
reorganiza el escenario material para que las relaciones jurídicas que dan vida a los terceros adquirentes -y los conflictos que le son inherentes-, germinen en la sociedad cubana. No se puede perder de vista que la nueva era del Registro de la Propiedad comienza a mediados de la década de los noventa del siglo pasado, cuando resulta necesario habilitarlo para brindar seguridad jurídica a los inversionistas extranjeros; proceso que se logra paulatinamente bajo el impulso del Ministerio de Justicia, que a través de varias disposiciones jurídicas logra despertar la publicidad inmobiliaria registral ${ }^{10}$. Hacia noviembre de 2011, el Registro funciona en todo el país, por lo que se establece como garantía de la formalización notarial de la compraventa de vivienda, la previa inscripción registral.

Sin embargo, como es de suponer, el desgaste no solo de estos sujetos como categoría jurídica merecedora de protección privilegiada en presencia de ciertos requisitos, sino de la fuerza misma de la inscripción registral y su incidencia en las relaciones civiles, las que se caracterizan durante años por el efecto de arrastre de las nulidades inmobiliarias -de permutas

https://www.pcc.cu/sites/default/files/documento/pdf/-20180426/lineamientos-politicapartido-cuba.pdf, consultado el 7 de julio de 2020, 9:35 am.

10 Decreto Ley Núm. 185, Modificativo de la Ley Número 65 de 23 de diciembre de 1988, "Ley General de la Vivienda", de 28 de mayo de 1998, publicado en la en Gaceta Oficial de la República de Cuba, Núm. 2, edición Extraordinaria, de 6 de julio de 1998. Resolución Núm. 247 del Ministro de Justicia, “Normas para la inscripción de los inmuebles, títulos y derechos reales en el Registro de la Propiedad", de 15 de septiembre de 2003, publicada en la Gaceta Oficial Gaceta Oficial de la República Núm. 16, edición Extraordinaria, de fecha primero de octubre de 2003. Resolución Núm. 249/2005 del Ministro de Justicia, “Normas y procedimientos para la nueva organización y funcionamiento del Registro de la Propiedad", de 7 de octubre de 2005, publicada en la Gaceta Oficial de la República de Cuba, Núm. 28, edición Extraordinaria, de 28 de octubre de 2005; en vigor desde el $1^{\circ}$ de diciembre de 2005. Resolución Núm. 114 de la Ministra de Justicia, "Las normas y procedimientos para la organización y funcionamiento del Registro de la Propiedad", de 29 de junio de 2007, publicada en la Gaceta Oficial de la República de Cuba, Núm. 39, edición Extraordinaria, de 6 de agosto de 2007. Junto a la última de estas disposiciones que es la que se encuentra vigente, también integra el actual ordenamiento registral el Decreto Ley Núm. 335, Del Sistema de Registros Públicos de la República de Cuba, de 20 de noviembre de 2015, publicado en la Gaceta Oficial de la República de Cuba, Núm. 40, edición Extraordinaria, de 14 de diciembre de 2015. 
y donaciones con viso de ilegalidad- y por la tutela de los derechos de verdaderos propietarios, influyen, sobremanera, en las soluciones ofrecidas a partir de noviembre de 2011 por los tribunales cubanos, en especial, su máximo foro de justicia, a cuyas decisiones particulares se aproxima este artículo. Incide desfavorablemente, además, el contexto legislativo.

En el ámbito estrictamente sustantivo, ni el Código Civil $(\mathrm{CC})^{11}$ ni la Ley General de la Vivienda $(\mathrm{LGV})^{12}$, reconocen los derechos de terceros adquirentes ${ }^{13}$. Por su parte, del análisis de la normativa registral se deduce que existe un marco legal promovido por el Ministerio de Justicia que regula desde el punto de vista organizativo y procedimental el Registro de la Propiedad; empero, excepto determinados efectos generales destinados a regir su estructura y funcionamiento ${ }^{14}$, resulta imposible distinguir -dentro de todo el marco regulatorio- otros efectos relacionados especialmente con la inscripción. De ahí que deba acudirse al artículo 34 de la LHU, en su razón de texto legal supletorio $^{15}$, para sustentar legalmente las adquisiciones a favor de los terceros adquirentes de viviendas.

11 Ley Núm. 59, Código Civil, promulgada el 16 de julio de 1987, vigente desde 12 de abril de 1988, publicada en la Gaceta Oficial de la República de Cuba, Núm. 9, edición Extraordinaria, de 15 de octubre de 1987. Vid. PÉREZ GALLARDO, Leonardo B. (2017). Código Civil de la República de Cuba, Ley N 59/1987 (Anotado y concordado). Ed. Ediciones ONBC, La Habana.

12 Ley Núm. 65 de 23 de diciembre de 1988, publicada en la Gaceta Oficial de la República de Cuba, Núm. 3, edición Extraordinaria, de 8 de febrero de 1989.

13 Salvo los artículos 84 y 192 del Código Civil, ningún otro precepto establece alguna pauta expresa que, con sus limitaciones, pudiere beneficiarles, pero estos se aplican a adquirentes de bienes muebles.

14 Cfr. artículos 5.1 y 5.2 del Decreto Ley Núm. 335, Del Sistema de Registros Públicos de la República de Cuba, de 20 de noviembre de 2015, publicado en la Gaceta Oficial de la República de Cuba, Núm. 40, edición Extraordinaria, de 14 de diciembre de 2015, en vigor a partir de su publicación oficial. Consúltese además la Resolución Núm. 114 de la Ministra de Justicia, "Las normas y procedimientos para la organización y funcionamiento del Registro de la Propiedad", de 29 de junio de 2007, publicada en la Gaceta Oficial de la República de Cuba, Núm. 39, edición Extraordinaria, de 6 de agosto de 2007, en vigor a los 30 días de su publicación oficial.

15 El carácter supletorio de la LHU ha sido reconocido por García Henríquez en relación con la Resolución Núm. 249/2005 dictada por el Ministro de Justicia -que antecede a la 
A más de un siglo de su promulgación, varios son los factores que atentan contra la aplicación del contenido de la LHU como cuerpo legislativo, lo que redunda en insuficiencias del régimen jurídico aplicable al aseguramiento del derecho de propiedad sobre bienes inmuebles y a la protección de los sujetos que constituyen el centro de atención de este estudio. Las derogaciones parciales que ha sufrido, la inaplicación de facto de sus preceptos por no ajustarse en cierto momento histórico -como se ha dicho- la realidad material al orden jurídico por ella establecido, el desuso por más de treinta años de las oficinas registrales, con la consiguiente interrupción del tracto sucesivo en la inscripción de los bienes inmuebles, o la falta de incentivos y de cultura de inscribir por parte la población, sin dudas repercuten negativamente en el reconocimiento de la eficacia del Registro de la Propiedad y en la pertinencia de la fe pública para legitimar las adquisiciones a non domino ${ }^{16}$.

actual Resolución Núm. 114/2007, del propio organismo-, cuando expresa: “(...) aquellas cuestiones que no se encuentran expresamente reguladas en la referida resolución, le son aplicables las normas que aún mantienen vigencia de la Ley Hipotecaria de 1893 y su Reglamento, que tienen un carácter supletorio de las disposiciones contenidas en la Ley General de la Vivienda, relativas al Registro de la Propiedad". GARCÍA HENRÍOUEZ, Francisco E. (2006). "Nuevo registro de la propiedad y ordenamiento inmobiliario en Cuba", en Boletín Oficial Registro Mercantil Central, Ministerio de Justicia, Vol. 2, Núm. 1, p. 38. Asimismo, FERNÁNDEZ MARTÍNEZ, Alfaro Guillén y ROSABAL ROBAINA, sostienen que: "Tanto el aspecto sustancial de la contratación como su dimensión registral están regulados por cuerpos normativos relativamente vigentes, que tienen como antecedentes el Código civil y la Ley Hipotecaria de Ultramar, a nuestro juicio en ambos casos con vocación de supletoriedad". Vid. FERNÁNDEZ MARTínEZ, Marta, ALFARO GUILLEN, Yanet y ROBAINA, Yuniel (2019). "Publicidad, seguridad jurídica y tercero inmobiliario. Apuntes teóricos y jurisprudenciales de cara al debate de su necesaria protección en Cuba", en Revista Crítica de Derecho Inmobiliario, Año XCV, Núm.773, Madrid, mayo-junio, pp. 1363.

16 Para profundizar en las adquisiciones a non domino, vid. SÁNCHEZ HERNÁNDEZ, Carmen (2001). "Breves reflexiones sobre las adquisiciones a non domino de inmuebles en el Ordenamiento alemán", en Anuario de Derecho Civil, Núm. LIV, fascículo 4, octubre, pp. 15551595; CÁRCABA FERNÁNDEZ, María (1985). “Configuración doctrinal de las adquisiciones "a non domino", en Revista Crítica de Derecho Inmobiliario, Núm. 567, Madrid, marzo-abril, 1985, pp. 343-352; FONT BOIX, Vicente (1967). "La adquisición «a non domino»", en Revista Crítica de Derecho Inmobiliario, Año XLIII, Núm. 463, Madrid, noviembre-diciembre, 1967, pp. 1607-1640. 
Esta situación ha motivado en operadores del Derecho, principalmente en jueces y magistrados -también en especialistas y teóricos- de la Isla, distintas interpretaciones en torno al vigor y validez de la LHU, con trascendencia a la aptitud -o ineptitud- de su andamiaje categorial y de principios para solventar los conflictos relativos a la propiedad inmobiliaria inscrita, en particular, los relativos a terceros adquirentes.

\section{La configuración de la desprotección a los terceros adquirentes de viviendas mediante compraventa por parte del Tribunal Supremo Popular de la República de Cuba: principales tendencias}

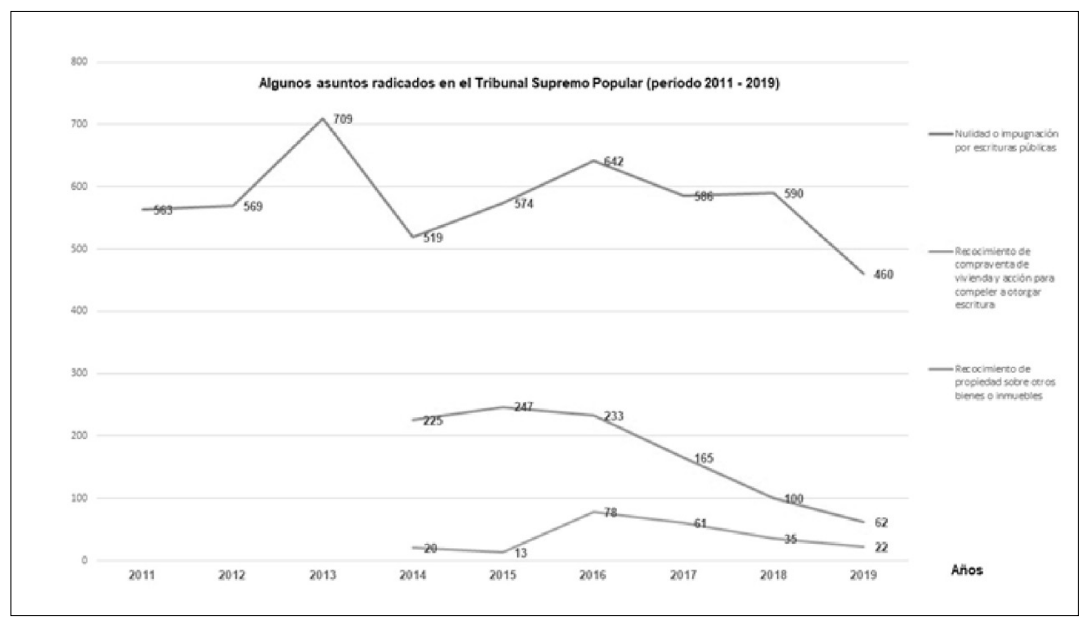

Fuente: Elaboración propia a partir de las estadísticas de la Dirección de Organización, Planificación e Información del TSP (2011-2019)

En consonancia con los cambios ocurridos a partir del Decreto Ley Núm. 288/2011, se suscitan reclamaciones ante los tribunales en aras -fundamentalmente- de anular o impugnar las escrituras públicas, así como de reconocer actos de compraventa anteriores a la entrada en vigor de dicha norma; sin embargo, no resulta constatable -desde el punto de vista 
estadístico $^{17}$, a través del gráfico siguiente- en cuántos de los casos se presenta la arista de salvaguarda al tercero adquirente y, además, tampoco constituyen fiel representación del universo de procesos promovidos al respecto, pues solo se reflejan los conocidos en la máxima instancia.

Por otro lado, resulta tarea complicada detectar o establecer un razonamiento uniforme en la solución de conflictos a tenor de las disímiles posiciones asumidas por la Sala de especialidad del TSP cubano, ante situaciones fácticas y legales de similar índole; sin embargo, se puede afirmar que, a partir de 2011, se ha transitado por tres etapas en el ámbito decisorio en lo que a protección -o desprotección- de terceros adquirentes se refiere, relacionadas con la existencia de lineas de pensamiento que pueden resumirse en:

$\left.1^{a}\right)$ Efecto absoluto del arrastre de nulidades $u$ otras causales de ineficacia sobre posteriores actos o negocios traslativos del dominio

Con anterioridad a la entrada en vigor del Decreto Ley Núm. 288/2011, solo se declara la nulidad en cadena de contratos de permutas o donaciones con ánimo de lucro, con incidencia en las compraventas subyacentes; todo ello sin que medien pronunciamientos sobre los posibles terceros adquirentes, ya sea por el desconocimiento de la figura e instituciones afines o por la endeble arquitectura registral que necesariamente le ha

\footnotetext{
17 Ante la respuesta de la Dirección de Organización, Planificación e Información del Tribunal Supremo Popular de la República de Cuba (en lo adelante, TSP) de no tener contabilizados los casos en que se discute sobre la protección a los terceros adquirentes, se solicita y obtiene la información sobre los asuntos en los que -a juicio de esta autora- puede constituir pretensión principal o subsidiaria; a saber: nulidad o impugnación de escrituras públicas, reconocimiento de compraventa de vivienda y acción para compeler a otorgar escritura, reconocimiento de propiedad sobre otros bienes o inmuebles. La solicitud en cuestión se extiende a los datos estadísticos relacionados con procesos de nulidad y otros ordinarios, de 2011 a la actualidad, para conocer el índice de procesos de reconocimiento de la compraventa de vivienda, de nulidad de contrato de compraventa u otras causales de ineficacia y reivindicatorios.
} 
de soportar. A partir de noviembre de ese propio año, comienza una especie de revolución intelectual en el gremio jurídico en torno a las posibilidades que brinda la nueva normativa y su repercusión en el tráfico inmobiliario. Así, comienzan a promoverse los reconocimientos de contratos de compraventa previamente celebrados ${ }^{18}$ y puede decirse que resurge la figura del tercero adquirente.

En sentido general, con el Decreto Ley y hasta unos cinco años más tarde, se abre espacio a reconocimientos de contratos de compraventa y a reclamaciones relacionadas con su nulidad o invalidez, ello con un criterio favorable en sede jurisdiccional y que trae como consecuencia el arrastre de la ineficacia en la cadena transmisiva.

18 Resulta emblemática la sentencia del TSP Núm. 46, de 28 de febrero de 2013, de la Sala de lo Civil y de lo Administrativo, que reconoce un contrato de compraventa celebrado en el año 1998, reconocimiento judicial que se interesa en el año 2012, ante la ausencia de disposiciones transitorias en el Decreto Ley Núm. 288/2011. El tribunal actuante razona en su primer Considerando "(...) la marcada injusticia que trae consigo no atribuirle a la relación negocial entre los litigantes instituida, los favorables efectos que la novedosa norma inmobiliaria les reconoce de cara a formalizar el contrato realizado con la obtención de pertinente titularidad a favor del comprador $(\ldots)^{\prime \prime}$, una vez comprobados los elementos de hecho que apuntan hacia la constatación fáctica objeto de tutela, a pesar de que su validez y eficacia estuviera vedada legalmente al momento de su perfección. Pondera el juzgador entre legalidad y justicia, con apego a los objetivos de la actividad judicial de "cumplir y hacer cumplir la legalidad socialista y amparar los intereses legítimos de los ciudadanos", como se deduce del segundo Considerando. Recurso de Casación Civil radicado al expediente Núm. 492 de 2012, interpuesto contra la Sentencia Núm. 101 de 21 de agosto de 2014, dictada por la Sala Primera de lo Civil y de lo Administrativo del Tribunal Provincial Popular de La Habana, en proceso civil ordinario Núm. 62 de 2012, sobre Reconocimiento de contrato de compraventa y condena a cumplir la obligación de otorgar la escritura pública ante Notario. Interesante comentario acerca de esta sentencia puede consultarse en, VELAZCO MUGARRA, Miriam (2013). "Comentario a la Sentencia No. 46 de 28 de febrero de 2013, de la Sala de lo Civil y de lo Administrativo del Tribunal Supremo Popular", en Boletín ONBC, Núm. 47, enero-marzo, 2013, pp. 71-75. La nueva era que apertura la citada resolución judicial conduce a la emisión de la Circular Núm. 265 del Presidente del TSP, de 2 de abril de 2013; disposición que en su apartado tercero establece que los tribunales tienen la obligación de viabilizar la participación de terceros interesados en el proceso, e incluso Ilamarlos de oficio, cuando ello resulte necesario. Terceros que pueden resultar, en no pocos casos, terceros adquirentes, arropados bajo la condición de terceros hipotecarios. 


\section{$\left.2^{a}\right)$ Vocación relativamente protectora}

Aunque existen predecesoras decisiones que confieren cierta protección al tercero adquirente, es la sentencia del TSP Núm. 114 de 28 de febrero de $2017^{19}$ la que marca un hito en la solución de los conflictos, sin que pueda aludirse a un giro jurisprudencial en virtud de los devaneos judiciales anteriores y posteriores ${ }^{20}$. La sentencia reconoce valor a la inscripción en el Registro de la Propiedad, alude a la seguridad jurídica que ofrece y pondera derecho a la herencia con el derecho de propiedad adquirido de buena fe por el tercero, con prevalencia de este último. Así, la Sala aprecia en su primer Considerando que: “(...) en el caso aun cuando la ahora no recurrente fue omitida en el acto de adjudicación hereditaria cuya nulidad se pretende, la Escritura que lo contiene fue debidamente inscripta en el Registro de la Propiedad inmobiliario y cumplido ese trámite, que obviamente imprime de certeza y seguridad jurídica a actos jurídicos posteriores, fue vendida la vivienda objeto de la adjudicación a los ahora recurrentes, que asisten al proceso en su carácter de terceros que han actuado de buena fe (...)".

Posteriores sentencias, con diversos criterios como sustento y aisladas en el tiempo, también protegen al tercero adquirente, sin que resulte previsible -sobre la base de una certeza de salvaguarda- el pronunciamiento judicial, pues con supuestos fácticos similares y en fechas cercanas, iguales ponentes fallan de manera diferente.

\footnotetext{
19 Recurso de Casación Civil radicado al expediente Núm. 1001 de 2016, interpuesto contra la Sentencia Núm. 252, de 30 de septiembre de 2016, dictada por la Sala Primera de lo Civil y de lo Administrativo del Tribunal Provincial Popular de La Habana, que resuelve el proceso ordinario Núm. 60 de 2016, sobre Nulidad de Acto Jurídico de Adjudicación de Herencia contenido en escritura notarial.
}

20 Al respecto, la reciente doctrina patria ha sostenido que "Habrá entonces dictados aislados, dicotómicos, variación temporal o como deba llamársele, pero no criterios jurisprudenciales, por la consolidación que ha de tener la «doctrina» sentada por el juez, en el sentido de su perdurabilidad, más allá de su repetición, cuestiones claramente diferentes". FERNÁNDEZ MARTÍNEZ, Marta, ALFARO GUILLÉN, Yanet y ROBAINA, Yuniel Rosabal. "Publicidad, seguridad jurídica y tercero inmobiliario...", cit., p. 1365. 
$\left.3^{a}\right)$ Prevalencia de la no tuición de los terceros adquirentes

Los pronunciamientos judiciales esperanzadores ${ }^{21}$ no han sido óbice para establecer criterios en contra de la protección a los terceros adquirentes de viviendas, ciertamente mayoritarios. Ello no solo pone de relieve la falta de una posición uniforme en la máxima judicatura, que regresa -a menudo- a la primera línea de pensamiento con aciago olvido del valor de la inscripción registral y de la necesaria seguridad del tráfico jurídico; sino también la falta de confianza -de los justiciables y de la propia judicatura en la instancia- ante la ausencia de una línea única de solución de estas discrepancias.

Constantemente se retrocede al mismo efecto de la época en que el tráfico de viviendas se reduce a la permuta y de donación a favor de determinadas personas, bajo control administrativo y en desmedro de la actividad registral o en correspondencia con aquellos tempranos años en que se cuajan los conflictos típicos de terceros adquirentes; razonamientos descontextualizados que requieren de sensibilización y actualización doctrinal y normativa.

Si bien a través del análisis de sentencias se advierte la inexistencia de una única postura en la solución de conflictos en relación a los terceros adquirentes de viviendas, además de la ausencia de una o varias líneas estables y concisas, es lo cierto que constituye una técnica de investigación que, de conjunto con otras, permite establecer tendencias -por asíllamarle-en el pensamiento y la orientación de la argumentación de la máxima judicatura patria sobre la protección a estos particulares sujetos que intervienen en el tráfico.

\section{Tendencia núm. 1: Alcance conceptual}

Llama la atención cómo un constructo jurídico de compleja composición e intelección, no ha sido definido oportunamente

\footnotetext{
21 Cfr. Sentencias del TSP Núm. 620 de 9 de agosto de 2016, Núm. 114 de 28 de febrero de 2017, Núm. 1062 de 29 de diciembre de 2017, Núm. 49 de 11 de febrero de 2019, Núm. 64 de 15 de febrero de 2019, Núm. 463, de 18 de julio de 2019, Núm. 601 de 20 de agosto de 2019 y Núm. 212 de 30 de agosto de 2019. Los datos restantes relativos a cada una de ellas, se consignan posteriormente, al ser referenciadas durante el análisis.
} 
por la magistratura cubana. La ausencia de una delimitación conceptual o de elementos que le perfilen, y de los requisitos para recibir especial tutela del ordenamiento jurídico, resulta evidente. Ello ha motivado errores conceptuales que trascienden a los fundamentos jurídicos que sostienen las posturas de las partes y del tribunal en sus respectivos actos procesales, fundamentalmente en los relativos a la toma de decisiones judiciales.

Así, con cierta frecuencia, se califica como tercero adquirente de buena fe al comprador o donatario que ha recibido el dominio de una vivienda en la que residen convivientes protegidos por el artículo 65 de la LGV, que ahora solicitan la declaración de nulidad del contrato celebrado al amparo del artículo 70, apartado 5, de la propia ley. En este caso, el comprador o donatario no es tercero adquirente, aunque actúe de buena fe -lo que ha de traducirse en desconocimiento de la existencia del conviviente-, toda vez que él es parte del contrato afectado por la causal de nulidad. No es tercero, sino parte contractual.

La sentencia del TSP Núm. 710, de 30 de octubre de $2017^{22}$ ilustra al respecto. Se trata de un fallo en casación que, en su primer Considerando, dispone: "(...) la situación de hecho que se integra como cierta a la sentencia deriva lógica y razonablemente de la adecuada valoración de los distintos medios que conforman el material de conocimiento aportado, incluyendo las cuestionadas, cuyos resultados individuales y de conjunto no arrojan elementos de juicio que favorezcan la especial protección que como conviviente alude cercenada por la vigencia de los distintos actos jurídicos que impugna, con soslayo de que dicha condición la abandonó por sí con anterioridad a que

22 Recurso de Casación Civil radicado al expediente Núm. 510 de 2017, interpuesto contra la Sentencia Núm. 25 de 10 de marzo de 2017, dictada por la Sala de lo Civil, de lo Administrativo y de lo Laboral del Tribunal Provincial Popular de Matanzas, que resuelve el proceso civil ordinario Núm. 230 de 2016, sobre Nulidad de acto jurídico contenido en escritura pública notarial. 
se formalizaran, despojándose voluntariamente de la cohabitación que realizaba del inmueble objeto de enajenación, en tanto no consta que en su contra haya accionado el otrora titular para obstruir su permanencia en la controversial vivienda, al tiempo que siendo originalmente una unidad física inmobiliaria, fraccionada a favor de tercero quien la adquirió por compraventa mediante escritura pública notarial (...) de dos mil catorce, momento en que ya había hecho dejación de su residencia en el recinto desde el año dos mil trece, tras lo cual tuvo lugar otro acto de disposición sobre la vivienda que en planta alta el propietario reservó para sí, mediante contrato de compraventa (...), sin que obre constancia de haber accionado activa y diligentemente a partir de la situación de conflicto que alega, a raíz de los mentados sucesos, y en defensa de los derechos ocupacionales que esgrime, contra su otrora titular antes de que abandonara el territorio nacional, en tanto hacerlo contra los adquirentes de buena fe, no justifica la tutela judicial que invoca".

Asimismo, la sentencia Núm. 180, de 6 de marzo de $2018^{23}$ que resuelve el recurso de casación interpuesto por la compradora de una vivienda, perjudicada por la declaración de nulidad del contrato celebrado entre ella y la hija del demandante, quien al día siguiente de la formalización del acto abandona el país dejando en estado de desprotección a su padre (anterior propietario de la vivienda, recluido al momento de la venta en un establecimiento penitenciario) dispone en su segundo Considerando que: "(...) el derecho del conviviente desprotegido con la controvertida compraventa inmobiliaria debe atenderse con prelación al de la compradora que actuó de buena fe al desconocer la causal de ineficacia que invalidaba el negocio concertado (...)".

23 Recurso de Casación Civil radicado al expediente Núm. 29 de 2018, interpuesto contra la Sentencia Núm. 207, de 31 de julio de 2017, dictada por la Sala Segunda de lo Civil y de lo Administrativo del Tribunal Provincial Popular de La Habana, que resuelve el proceso civil ordinario número 9 de 2016, sobre Nulidad de Contrato de Compraventa. 
Otras sentencias del TSP como las Núm. $25^{24}$ y Núm. $35^{25}$, ambas de 31 de enero de 2020, evidencian los desacertados criterios manejados por los operadores en la instancia, al alegar y acoger excepciones perentorias aparentemente con sustento teórico adecuado. Así, una aparece bajo la denominación de protección de derechos de terceros adquirentes de buena fe, cuando realmente solo existe un sujeto en esta condición, al haber acontecido dos compraventas sucesivas y solo existir la posibilidad de vicio de nulidad en cuanto a la primera de ellas; otra, como consagración de la buena fe a favor del tercero comprador y de la expropietaria vendedora, sin embargo, las adjudicatarias celebran un contrato de compraventa cuya validez es atacada por un supuesto conviviente protegido, luego, el comprador es parte en el contrato objeto de nulidad, no es tercero, y su buena o mala fe es intrascendente.

\section{Tendencia núm. 2: Norma aplicable}

A consecuencia de la túrbida evolución de la actividad registral cubana, la inoperancia de la LHU por tantos años y el desuso de instituciones concordantes, los primeros casos presentados en los tribunales, a raíz de la puesta en vigor del Decreto Ley Núm. 288/2011, encuentran fundamento jurídico en los principios generales de buena fe (ex artículo 6 del CC), prohibición de abuso del derecho (ex artículo 4 del CC) y en menor medida -paradójicamente-, en el principio de seguridad jurídica. La invocación de la preceptiva registral resulta esquiva hasta hace aproximadamente tres años, ya que los representantes letrados de terceros adquirentes comienzan a sustentar sus

\footnotetext{
24 Recurso de Casación Civil radicado al expediente Núm. 963 de 2019, interpuesto contra la Sentencia Núm. 103, de 28 de junio de 2019, dictada por la Sala Segunda de lo Civil y de lo Administrativo del Tribunal Provincial Popular de La Habana en el proceso ordinario Núm. 226 de 2018, sobre Nulidad de Contrato de Compraventa de Vivienda.

25 Recurso de Casación Civil radicado al expediente Núm. 885 de 2019, interpuesto contra la Sentencia Núm. 109 de 31 de julio de 2019, dictada por la Sala Primera de lo Civil y de lo Administrativo del Tribunal Provincial Popular de La Habana, que resuelve el proceso civil ordinario Núm. 105 de 2018, sobre Nulidad de acto jurídico.
} 
escritos polémicos en la Resolución Núm. 114/2007 de la Ministra de Justicia, en relación con los artículos. 33 y 34 de la LHU. Del estudio de las sentencias dictadas por la Sala de lo Civil y de lo Administrativo del TSP desde 2011 hasta la fecha, se constata esta realidad, fundamentalmente, a partir de 2018.

Sin embargo, la invocación no se refleja en su aplicación, que ha sido mucho más reservada. Salvo halagüeños fallos a nivel provincial ${ }^{26}$, que reconocen la eficacia de los artículos mencionados y, por ende, la vigencia y validez de la LHU en la materia objeto de estudio, la Sala de la especialidad del alto foro no ha asumido -como criterio general- su pertinencia para solventar este tipo de conflictos, a pesar de haber sido esgrimidos. Valoraciones superficiales en torno al desfase del cuerpo normativo con el actual escenario y su supuesta ineptitud para regir las relaciones constituidas en el pleno siglo XXI, han cercenado la viabilidad de la fe pública registral -fundamento legal ad hoc que ni siquiera se trae a colación en los razonamientos del tribunal- para atribuir la regla de propiedad a favor de los terceros adquirentes de viviendas ${ }^{27}$.

26 Se hace referencia a la Sentencia Núm. 118 de 31 de julio de 2018, de la Sala Segunda de lo Civil y de lo Administrativo del Tribunal Provincial Popular de La Habana, dictada en el proceso civil ordinario Núm. 32 de 2018, sobre Nulidad de acto jurídico contenido en escritura pública notarial, ratificada por la sentencia del TSP Núm. 64 de 15 de febrero de 2019, Recurso de Casación Civil radicado al expediente Núm. 952 de 2018; y las sentencias Núm. 137 de 31 de agosto de 2018 y Núm. 203, de 21 de noviembre de 2019, de la propia sala, dictadas en los procesos civiles ordinarios Núm. 414 de 2017 y Núm. 34 de 2019, respectivamente, teniendo por objeto declarar la nulidad de actos jurídicos contenidos en escrituras públicas notariales.

27 La tutela privilegiada a favor del tercero adquirente se concreta mediante la atribución de una regla de propiedad que permite el mantenimiento del derecho real adquirido, y con ello que el contrato traslativo celebrado cumpla su finalidad. Ello implica, que el titular civil debe ser protegido mediante una regla de responsabilidad. Sobre el rejuego de estas reglas, en este tipo de conflictos, consúltese CALABRESI, Guido y MELAMED, A. Douglas (1996). “Reglas de propiedad, reglas de responsabilidad y de inalienabilidad: Una vista de la catedral", traducido al castellano por el Centro de Estudios Públicos, en Revista de Estudios Públicos, Núm. 63, invierno, pp. 349 y 350; y, particularmente, MÉNDEZ GONZÁLEZ, Fernando P. (2013). "Derechos reales y titularidades reales", en Revista Crítica de Derecho Inmobiliario, Año LXXXIX, Núm. 736, marzo-abril, pp. 763-860. 
Así se colige de la sentencia del TSP Núm. 815, de 21 de noviembre de $2018^{28}$ cuando en su segundo Considerando dispone que"(...) la Ley Hipotecaria, legislación cuya vigencia data de la segunda mitad del siglo diecinueve y que, en consecuencia, ha de aplicarse con la debida reserva en nuestro contexto actual, al que no se aviene por obvias razones de obsolescencia, pese a lo cual, su artículo treinta y tres deja sentado que la inscripción registral -por demás también declarada ineficaz por la presente- no convalida la nulidad del acto ilícito y si bien su artículo treinta y cuatro refrenda que dicha ineficacia no debe extenderse a terceros, luego de que estos hubieran inscripto su adquisición (...) es lo cierto que tal requerimiento resulta inaplicable en nuestro contexto actual (...)”.

Esta postura sobre la obsolescencia y el desfase de los postulados de la LHU, respecto al contexto cubano actual -que se reitera en las sentencias Núm. 127 de 18 de marzo de 2019 (tercer Considerando) ${ }^{29}$ y Núm. 725 de 23 de octubre de 2019 (único Considerando $)^{30}$ - no supone, obviamente, una derogación tácita de su contenido interno, pero tampoco puede traducirse en inaplicación a ultranza de su preceptiva. En el escenario actual, la inobservancia jurisdiccional, especialmente, de los artículos 33 y 34 de la LHU -aunque por más de cincuenta años durmieran el sueño eterno- no se justifica. Si no se encuentran

28 Recurso de Casación Civil radicado al expediente Núm. 769 de 2018, interpuesto contra la Sentencia Núm. 84, de 25 de junio de 2018, dictada por la Sala Primera de lo Civil y de lo Administrativo del Tribunal Provincial Popular de La Habana, en el proceso ordinario Núm. 279 de 2018, sobre Nulidad de Actos Jurídicos de Permuta de Viviendas, Unificación de Viviendas y Cesión de Participación, contenidos en escrituras públicas.

29 Recurso de casación civil radicado al expediente Núm. 39 de 2019, contra la Sentencia Núm. 176, de 18 de octubre de 2018, dictada por la Sala Primera de lo Civil y de lo Administrativo del TTP de La Habana, que resuelve el proceso civil ordinario Núm. 7 de 2018, sobre Nulidad de Aceptación y Adjudicación de Herencia Intestada y Compraventa de Vivienda.

30 Recurso de Casación Civil radicado al expediente Núm. 707 de 2019, interpuesto contra la Sentencia Núm. 217, de 28 de diciembre de 2018, dictada por la Sala Segunda de lo Civil y de lo Administrativo del Tribunal Provincial Popular de La Habana, en el proceso civil ordinario Núm. 268 de 2017, sobre Nulidad de Actos Jurídicos de Unificación de Viviendas y Constitución de Copropiedad por Cuotas, Cesión de Participación y Permuta de Viviendas. 
formalmente derogados porque ninguna de las normas posteriores que instrumentan la publicidad inmobiliaria registral en el país los han derogado expresamente, así como tampoco lo han hecho de modo tácito, por no haberse dispuesto un régimen posterior que dé al traste con sus efectos originarios contenidos en la LHU -que indique una derogación tácita de su contenido por incompatibilidad técnica-, ambos preceptos continúan en vigor $^{31}$. Luego, lo que puede cuestionarse es su validez material, o sea, si pueden ser exigidos por sus destinatarios en una coyuntura determinada.

Para ello, es preciso recurrir a la esencia del fenómeno, a la ratio de la norma y valorar su apego a las circunstancias actuales. Aflora entonces la necesidad y utilidad específica del artículo 34, debido a la existencia de hechos sociales que hacen reclamar su aplicabilidad. La presencia de terceros adquirentes, en defensa del derecho subjetivo que creen vulnerado, e incluso, los imprecisos fallos emitidos por la judicatura patria, al tiempo que corroboran dicho estado, confirman la validez material del precepto en cuestión. Así, el artículo de referencia existe, conserva su vigencia y es válido formal y materialmente; pero, sobre todo, resulta útil y necesario a los intereses de sus destinatarios, lo que tributa, entre otros factores, a su potencial eficacia ${ }^{32}$.

Para dotar al tráfico jurídico de sólidas bases de certidumbre y confianza -a fin de potenciar la agilidad de los intercambios,

31 Al respecto consúltese, PRIETO VALDÉZ, Martha, "Validez, Vigencia, Eficacia y Legitimidad. Relación y distinción", en Cuba siglo XXI, Política, s.f., disponible en https://www. nodo50.org/cubasigloXXI/politica/-prieto5_310702.htm, consultado el 18 de septiembre de 2020, 6:34 a.m. Refiriéndose a los vínculos entre la vigencia y la validez formal indica Kelsen que "la norma entra en vigencia (...) ya sea por medio de un acto volitivo que la ha generado 0 por la costumbre. Cuando uno dice: "una norma tiene validez». se quiere decir que existe una norma. La "validez» es la existencia específica de una norma". KELSEN, Hans (1994). Teoría general de las normas, Ed. Trillas, México D.F., p. 20.

32 Ello depende, también, de la observancia de la norma por sus destinatarios y, sobre todo, de su correcta aplicación por los tribunales. Recuérdese que el término eficacia conduce a la concreción de un resultado, que en este caso implica el rescate de su contenido, que no su desecho, porque ello le tornaría inaplicable. 


\section{el crédito territorial y la inversión ${ }^{33}$-, la protección a los terceros adquirentes mediante la atribución de una regla de propiedad, deviene elemento cardinal. Sustentada en la apariencia de le- gitimación registral del transferente y la razonable confianza generada por la inscripción a favor del adquirente, la fe pública registral coadyuva a la consecución de la seguridad jurídica ${ }^{34}$.}

33 La respuesta del Derecho a los condicionamientos sociales y económicos es tal, que es el propio Estado cubano el que revitaliza la institución de la hipoteca inmobiliaria como garantía a los inversionistas extranjeros, con pleno reconocimiento de la vigencia de la LHU de 1893 como norma de aplicación (cfr. artículo 2 del Decreto Ley Núm. 214, Constitución de hipotecas sobre bienes inmuebles, de 24 de noviembre de 2000, publicado en la Gaceta Oficial de la República de Cuba, Núm. 9, Edición extraordinaria, de 29 de noviembre del propio año). Pero debe tenerse en cuenta que el contenido de la LHU y su reglamento es más amplio que la regulación de la hipoteca como garantía de los derechos de crédito, ya que ampara ciertas relaciones sociales que se pueden dar en el tráfico y que toman como punto de partida la inscripción registral, con vocación de ofrecer seguridad jurídica a los titulares registrales y sobre todo a terceros. Aunque el andamiaje registral de la propiedad inmobiliaria en Cuba y el tracto que de la inscripción genera se ve truncado por largo tiempo, precisamente porque el tráfico inmobiliario se ve reducido a su mínima expresión; es el mismo legislador patrio, a partir del Decreto Ley Núm. 185 de 1998, quien le rescata e intenta fortalecerle, primero como garantía para la inversión extranjera, y luego porque el tráfico se ve revitalizado al autorizarse la transmisión intervivos de bienes inmuebles, fundamentalmente por compraventa, a partir de 2011.

34 Respecto al concepto de seguridad jurídica, es dable resaltar la gran diversidad de formulaciones y de planteamientos teóricos de los que ha sido objeto. Ello se debe tanto a la polisemia propia del término seguridad, como a la amplia repercusión de la institución para el Derecho, el Estado y la sociedad. Pérez Luño señala, en este sentido, que “En el Estado de Derecho la seguridad jurídica asume unos perfiles definidos como: presupuesto del Derecho, pero no de cualquier forma de legalidad positiva, sino de aquella que dimana de los derechos fundamentales, es decir, los que fundamentan el entero orden constitucional; y función del Derecho que asegura la realización de las libertades. Con ello, la seguridad jurídica no sólo se inmuniza frente al riesgo de su manipulación, sino que se convierte en un valor jurídico ineludible para el logro de los restantes valores constitucionales". PÉREZ LUÑO, Antonio Enrique (2000) "La seguridad jurídica: una garantía del derecho y la justicia", en Boletín de la Facultad de Derecho, Núm. 15, p. 28.

La seguridad jurídica -calificada de plena según Vallet de Goytisolo- como aquella referida "(...) al Derecho tal cual es, en todo su contenido propio, y que se mueve, no en el campo de los valores, sino, en el de las titularidades de derecho". VALLET DE GOYTISOLO, Juan B.(2002) "Seguridad jurídica estática y seguridad jurídica dinámica", en Anuario Iberoamericano de Derecho Notarial, Núm. 1, p. 501. Se realza la eficacia de la seguridad para los derechos subjetivos en juego -más que para el Derecho en sí-, inalterables ante los que no han consentido, o no han podido conocer los respectivos titulares. Este tipo de seguridad 
Este objetivo conveniente e imprescindible en cualquier Estado de Derecho, no es exclusivo del momento histórico en que surge la LHU, no es incongruente con una economía planificada donde el Estado se arroga el control del mercado, no es antagónico con un sistema socioeconómico y político socialista, todo lo contrario. La seguridad de los derechos reales inmobiliarios adquiridos y de las transacciones que dan vida a su tráfico, se encuentran en plena sintonía con los presupuestos constitucionales y legales que definen el Estado cubano ${ }^{35}$ y proyectan su modelo económico y social ${ }^{36}$.

difiere de la económica o subsidiaria, que "no garantiza la titularidad del derecho, sino el valor que el derecho tiene, convertido en indemnización en caso de despojo". Ibídem.

35 La cuestión, en esta sede, no estriba en que el Estado responda a una ideología capitalista o socialista, sino en proteger el derecho de propiedad reconocido constitucional y legalmente (cfr. artículos 18, 19, 22 al 24, 29 y 30 de la Constitución de la República de Cuba de 10 de abril de 2019, publicada en Gaceta Oficial de la República Núm. 5, edición Extraordinaria, de 10 de abril de 2019). El Estado cubano reconoce el derecho de propiedad de las personas, por lo que, ante conflictos en torno a él, corresponde a los tribunales decidir a quién se le atribuye, según las circunstancias del caso, pero también con toma de conciencia de las normas que resultan de aplicación. No puede soslayarse que, en todo caso, se trata de un conflicto privado, cuyos litigantes se encuentran en un plano de igualdad respecto a la defensa de sus derechos; de ahí que corresponde al juzgador asignar, mediante la regla que mejor convenga, la propiedad a quien la impugna (titular civil) o dejarla en manos de quien la ostenta (tercero adquirente). Por lo tanto, un conflicto de esta naturaleza no rebasa los contornos de lo estrictamente privado, cuya única incidencia hacia lo público está dada por la inscripción registral y por la presencia de un tribunal en la solución del litigio, no porque contravenga el orden establecido jurídicamente.

36 El modelo económico y social cubano de desarrollo socialista reconoce expresamente que, para promover la prosperidad y el bienestar humano como ideales que transversalizan las políticas públicas, en particular, la social, resulta necesario "la consolidación de la estabilidad económica y social con seguridad y sin incertidumbres sobre cuestiones esenciales del futuro personal, familiar y colectivo de los ciudadanos". La cursiva es propia. Vid. "Conceptualización del modelo económico y social cubano de desarrollo socialista", julio de 2017. disponible en http://www.granma.cu/file/pdf/gaceta/Conceptualizaci\%C3\%B3n\%20del\%20 mo-delo\%20economico\%20social\%20Version\%20Final.pdf, consultado el 10 de octubre de 2020, 3:45 p.m., p. 43. Lo anterior encuentra expresión en el texto constitucional de 2019, al regularse como fin esencial del Estado cubano -ex artículo 13 inciso e- la promoción de un desarrollo sostenible que asegure la prosperidad individual y colectiva, y obtener mayores niveles de equidad y justicia social (...). 
Partiendo de su vocación de perpetuidad, de su legitimidad apriorística como "regla heredada" 37 , de la voluntad presunta del legislador de preservar la esencia y sustancia del artículo 34, la validez de su contenido se sustenta, también, en la estructura misma de la norma. Su hipótesis encierra una situación fáctica cuya materialización, en el escenario creado a partir de 2011, resulta perfectamente posible. Además, dada la operatividad de su consecuencia o sanción y la existencia de un mínimo de garantías jurídicas para ponerla en marcha, se concluye que, en principio, la norma jurídica se encuentra apta para ser aplicada. Es así que, ante el evidente cambio de circunstancias, la fe pública registral debe ser acogida por los tribunales en aras de sustentar la adquisición experimentada por el tercero de buena fe, a quien se le ha protegido, sin embargo, por otros cauces; por lo que sus intereses se han considerado, en determinados casos concretos, como dignos de tutela.

El reconocimiento de la vigencia de la LHU no ha sido, por consiguiente, sustancioso para provocar la aplicación del artículo 34 en sede jurisdiccional, la que se ha hecho esquiva debido al "análisis contextualizado de los elementos del caso"; cuestión que se utiliza como una cláusula de estilo, vacía de contenido, que no ofrece argumentos relevantes para negar la validez material del precepto en el supuesto en cuestión ${ }^{38}$. Si

37 Díez - Picazo denomina reglas heredadas a aquellas normas "( ...) cuya cristalización en textos procede de épocas anteriores", siendo recibidas por el sistema de gobierno constituido que las mantiene o conserva implícitamente. A su juicio, este fenómeno "(...) tiene mucho de aquiescencia e incluso, a veces, de inercia o pereza mental". Contrapone a ellas las Ilamadas reglas implantadas o directivas con pretensión de actuación y de eficacia inmediata, cuya génesis radica, por el contrario, "(...) en las decisiones rigurosamente coetáneas del sistema de gobierno constituido". DÍEZ-PICAZO, Luis (1987). Experiencias jurídicas y teoría del derecho, $2^{a}$ edición, Ed. Ariel, Barcelona, p. 31.

38 De hecho, mediante el Auto Núm. 89 de 31 de marzo de 2020, emitido por el alto foro para declarar inadmisible el proceso de revisión radicado al expediente Núm. 46 de 2020 en relación con la STSP Núm. 725, de 23 de octubre de 2019, dictada por la propia Sala de lo Civil y de lo Administrativo del TSP, al expresar que "(...) en su relato de la desprotección argüida, la demandante se limita a cuestionar la fundamentación de la sentencia de cuya impugnación se trata, que intenta resquebrajar al confrontarla con su personal interpretación 
la más alta magistratura valora que existen elementos que apuntan hacia su absoluta inaplicación o a su aplicación sujeta a ciertas cautelas o reservas ${ }^{39}$, tiene el deber de fundamentar fehacientemente su juicio y ser consecuente con él, habida cuenta de la razonable predictibilidad de las decisiones judiciales futuras; empero, ello no ha acontecido hasta la fecha.

La aplicación del artículo 34 con la "debida reserva" se ha convertido, en la práctica, en inobservancia tanto del efecto registral dimanante, como de la exigencia de los requisitos regulados por este para conferir protección mediante una regla de propiedad. Debe advertirse el peligro que encierra la utilización de la expresión entrecomillada como válvula de escape para no aplicar -casi nunca- el precepto y no proteger a los terceros adquirentes. Tal expresión implica, primero, que la norma que ampara la situación jurídica en cuestión está vigente y, segundo, que solo se deja de aplicar cuando razones extraordinarias lo ameriten. Añádase que la protección a los terceros adquirentes no es una cuestión de estricta ponderación de intereses, sino de subsunción, porque existe un filtro que estos sujetos deben pasar a través de la verificación de los requisitos tuitivos; elementos que, por su carácter legal, deben conducir a su amparo inmediato.

Al juez corresponde impartir justicia y ello ha de hacerse libremente, sin más obstáculos que los que la ley y su propia prudencia le imponen. Siendo así, cualquier referencia a la

de lo razonado, obviando que la resolución judicial, sin pasar por alto la vigencia de la invocada Ley Hipotecaria, pondera la aplicabilidad de su preceptiva de acuerdo a un análisis contextualizado de los elementos acreditados en el caso (...)", ha tenido que aclarar tal particular, reconociendo -de soslayo- su virtualidad, pero evita hacer referencia a cuáles son esos elementos determinantes de la decisión.

39 Es predominante el argumento de que el artículo 34 de la LHU debe aplicarse con precaución o "debida reserva", teniendo en cuenta, esencialmente, la peculiar situación socioeconómica que existe en el país en torno a la vivienda, fundamentalmente, el déficit habitacional, su carácter inejecutable, la función social que esta desempeña, entre otras. Se ha ponderado el derecho a la vivienda a favor del titular civil o el derecho a ocuparla a favor de los convivientes, por cuanto este peculiar inmueble, de alto valor económico, resulta neurálgico para el desarrollo de la vida familiar y personal; necesidad social que obviamente también puede concretarse en la persona de los terceros adquirentes. 
"debida reserva" sobra, pero ante la "necesidad" de convivir con ella, debe interpretarse como excepción y no como regla de actuación que, en todo caso, debe ser motivada y jurídicamente sostenible. El artículo 34 de la LHU goza de aplicabilidad jurídica debido a que contiene una norma vigente y apta para regular relaciones jurídicas que se materializan en la práctica a partir del año 2011.

De tal suerte, aquellos casos en que se favorece al tercero adquirente se han motivado a través de su buena $\mathrm{fe}^{40}$, de su conducta dirigida a no causar daño (expresión del no abuso del derecho $)^{41}$, de que han inscrito su adquisición en el Registro de la Propiedad (expresión de seguridad jurídica) o de que han confiado en cierta apariencia ${ }^{42}$; descartándose la genuina protección

40 STSP Núm. 620, de 9 de agosto de 2016, Recurso de Casación Civil radicado al expediente Núm. 327 de 2016, interpuesto contra la Sentencia Núm. 353 de 30 de diciembre de 2015, dictada por la Sala Segunda de lo Civil y de lo Administrativo del Tribunal Provincial Popular de La Habana, radicado al expediente 219 de 2015, contentivo de un proceso civil ordinario sobre Nulidad de contrato de compraventa de vivienda, la cual fundamenta la protección de los terceros adquirentes en su buena fe, en su actuación contractual diligente y en el carácter oneroso de las atribuciones patrimoniales que de ese contrato se suscitan; STSP Núm. 1062, de 29 de diciembre de 2017, Recurso de Casación Civil radicado al expediente Núm. 926 de 2017, interpuesto contra la Sentencia Núm. 110 de 30 de junio de 2017, dictada por la Sala Primera de lo Civil y de lo Administrativo del Tribunal Provincial Popular de La Habana, en el proceso civil ordinario Núm. 430 de 2017, sobre declaración de nulidad de acto jurídico de permuta de viviendas y STSP Núm. 601 de 20 de agosto de 2019, Recurso de Casación Civil radicado al expediente Núm. 449 de 2019, interpuesto contra la Sentencia Núm. 10, de 31 de enero de 2019, dictada por la Sala Primera de lo Civil y de lo Administrativo del Tribunal Provincial Popular de La Habana, en el proceso civil ordinario Núm. 165 de 2018, sobre Nulidad de actos jurídicos, ampara a los terceros adquirentes debido a su buena fe y el reconocimiento de la inacción sostenida de cotitular civil.

41 SSTSP Núm. 114, de 28 de febrero de 2017 y Núm. 49, de 11 de febrero de 2019, Recurso de Casación Civil radicado al expediente Núm. 855 de 2018, interpuesto contra la Sentencia Núm. 91, de 26 de junio de 2018, dictada por la Sala Segunda de lo Civil y de lo Administrativo del Tribunal Provincial Popular de La Habana, en el proceso civil ordinario Núm. 396 de 2018, sobre Nulidad de los Actos Jurídicos contenidos en las escrituras de Adjudicación de Vivienda y Contrato de Permuta, con la peculiaridad de que acoge la inacción sostenida del titular civil como derivación del ejercicio abusivo de su derecho.

42 STSP Núm. 463, de 18 de julio de 2019, Recurso de Casación Civil radicado al expediente Núm. 200 de 2019, interpuesto contra la Sentencia Núm. 1, de 11 de enero de 2019, dictada 
que origina el aseguramiento registral del derecho de propiedad y, en particular, de la fe pública registral.

\section{Tendencia núm. 3: Futilidad de la inscripción registral y otras inconsistencias técnicas}

Derivado de lo anterior, constituye tendencia el hecho de que se desconozca la condición de modo de aseguramiento al Registro de la Propiedad, con lo cual, pierde ocasión el alto foro de proveer valor a la inscripción y, de paso, incentivarla. En la mayoría de estos casos -sobre todo cuando se invoca el artículo 34 de la LHU-, las adquisiciones correspondientes han accedido al Registro, en búsqueda de un plus de protección, de una certidumbre adicional a la conferida a través de la formalización del título de propiedad. Por ello, resulta contradictorio que se obvie este particular, tanto en los escritos polémicos como en la fundamentación de la resolución judicial definitiva ${ }^{43}$.

La resistencia a aplicar disposiciones registrales vigentes, en particular, la LHU -única normativa que fija los efectos sustantivos de la inscripción- bajo el entendimiento de que se encuentra desfasada o que por "(...) arcaica, parte del contexto

por la Sala de lo Civil, de lo Administrativo, de lo Laboral y de lo Económico del Tribunal Provincial Popular de Ciego de Ávila, en el proceso civil ordinario Núm. 50 de 2018, sobre Nulidad de acto jurídico, que lo protege sobre la base de su buena fe y de la confianza en la apariencia jurídica y STSP Núm. 212 de 30 de agosto de 2019, Recurso de Casación Civil radicado al expediente Núm. 481 de 2019, interpuesto contra la Sentencia Núm. 20, de 28 de febrero de 2019, dictada por la Sala Primera de lo Civil y de lo Administrativo del Tribunal Provincial Popular de La Habana, en el proceso civil ordinario Núm. 63 de 2018, sobre Nulidad de acto jurídico, que da preeminencia a los principios de buena fe, el no abuso del derecho y la seguridad jurídica que rigen los actos y contratos válidos.

43 Vale traer a colación, entonces, el citado tercer Considerando de la sentencia del STP Núm. 127, que puntualiza: "(...) puesto que el derecho sobre el inmueble en conflicto de la adjudicataria que devino vendedora nació viciado y aun cuando se ha acreditado en el proceso que dicha titularidad hubiera sido inscripta en el correspondiente Registro de la Propiedad con antelación a la concertación del negocio de compraventa, es lo cierto que los ulteriores efectos de la declarada nulidad, en atención al derecho preferente dimanante en favor de la heredera omitida, debe alcanzar a la aludida tercero adquirente; puesto que tal carencia no puede redundar en la convalidación del acto ineficaz". 
ideal de la absoluta cobertura registral" ${ }^{44}$ que no se corresponde con la realidad actual -aunque tampoco con la de aquellos lejanos años en que se establece el sistema hipotecario español en los predios nacionales, ni los ulteriores-, ha traído consigo fundamentalmente dos inconsistencias técnicas.

En varios casos, el órgano juzgador razona que la tuición del tercero no resulta posible - aun y cuando se trae a colación el artículo 34 en relación con el 33- porque la nulidad del negocio antecedente irradia indefectiblemente al negocio adquisitivo del tercero; cuando, en puridad, la función por excelencia del primero de estos preceptos es bloquear el efecto de arrastre y salvaguardar la eficacia de la adquisición a non domino que, de plano, ha de ser válida porque de lo contrario, en virtud del artículo 33, no despliega sustantividad alguna la inscripción registral.

La referida sentencia Núm. 127 de 18 de marzo de 2019, en su segundo Considerando expresa: "(...) la titularidad derivada de la defectuosa adjudicación con que concurriera a la concertación del negocio de compraventa de vivienda (...) se encontraba viciada y es nula de origen, sin que, en consecuencia, proceda protección alguna a quien recurre, que aduce haber adquirido el inmueble con desconocimiento de tal impedimento".

Por otra parte, a sabiendas de la nulidad o -en general- de la invalidez del negocio antecedente, que hace decaer la relación jurídica determinante de la condición de tercero, y siendo manifiesto el ánimo de proteger a este último, se incurre en el error de no declarar la ineficacia en cuestión, para evitar el indeclinable efecto dominó sobre el título causal del tercero. Así, la sentencia Núm. 114 de 28 de febrero de 2017 del propio foro, en su único Considerando, razona que "(...) si bien ha sido criterio reiterado de esta Sala superior de justicia que la omisión de un beredero es causal de nulidad del acto de adjudicación, que con tal olvido haya acontecido, ya que además de violentar las disposiciones

44 Sentencia del TSP Núm. 815, de 21 de noviembre de 2018 (segundo Considerando) y Núm. de 23 de octubre de 2019 (único Considerando). 
de carácter sucesorio, no cumple con las formalidades que para tal acto se exige con perfil esencial, tal planteamiento no puede causar daño a terceros que bayan actuado de buena fe, y en el caso aun cuando la ahora no recurrente fue omitida en el acto de adjudicación hereditaria cuya nulidad se pretende, (...) fue vendida la vivienda objeto de la adjudicación a los ahora recurrentes, que asisten al proceso en su carácter de terceros que han actuado de buena fe, que serían perjudicados con la decisión de nulidad acordada por la Sala juzgadora, que desencadenaría, indefectiblemente la ineficacia de los actos posteriores, pues es principio (...) que este ejercicio no puede ser antifuncional o perjudicial a los derechos de terceros, como ocurre en el presente asunto, quedando a salvo la condición de beredera de la no recurrente con el ejercicio de la acción resarcitoria (...)" ${ }^{45}$.

Ambos ejemplos revelan, no solo incoherencias técnicas, al asumir posiciones extremas y contradictorias en sí, sino también errónea interpretación del precepto legal y de los presupuestos y principios que le informan. Ello denota, a su vez, aplicación de las reglas del Derecho Civil estricto, donde no se establece excepción alguna que resguarde -bajo una regla de propiedadla adquisición del tercero. De la mano de lo anterior, indirectamente se desconoce el principio de especialidad que determina la aplicación preponderante del ordenamiento registral, en materia de propiedad inmobiliaria inscrita ${ }^{46}$.

Como última precisión, una cuestión es el efecto de arrastre o dominó que produce la nulidad o ineficacia en cadena y otra -bien distinta- que se considere que el negocio adquisitivo del

\footnotetext{
45 Con meridiana cautela la sentencia del TSP Núm. 620, de 9 de agosto de 2016 enerva la nulidad en cadena para no afectar el contrato de compraventa celebrado entre la adjudicataria (que no la única con derecho) y el tercero adquirente de la vivienda; por ello en el primer Considerando se advierte que: "(...) debió la sentencia anterior sostenerse en la improcedencia de cercenar la vinculación contractual, ante la reversión económica que en metálico se produjo en el patrimonio de la no recurrente (...)".

46 Como referente bibliográfico, en este sentido, vid. LA RICA Y ARENAL, Ramón (1950). "Dualidad legislativa de nuestro régimen inmobiliario", en Revista Crítica de Derecho Inmobiliario, Año XXVI, Núm. 269, octubre, 1950, pp. 625-643.
} 
tercero es inválido de origen -nulidad absoluta- como consecuencia de los vicios, faltas o defectos derivados del acto o negocio antecedente. Tal apreciación constituye -en criterio propio- un craso error técnico, porque el contrato de compraventa celebrado entre tercero y transmitente, en este caso, puede considerarse ineficaz como consecuencia de la falta de legitimación para disponer que en su momento fuera cubierta por la legitimación registral; pero no puede considerarse inválido si han concurrido los elementos que determinan la validez negocial (consentimiento, el objeto, la causa y la forma, lo que incluye el cumplimiento de la formalidad exigida legalmente).

\section{Tendencia núm. 4: Buena fe del tercero adquirente}

De los cuatro requisitos de protección exigibles al tercero adquirente, constituye la buena fe el de mayor complejidad técnica en cuanto a su configuración, por ser el único que le imprime subjetividad al asunto, lo que dificulta su valoración caso a caso. Supone la concreción del principio de buena fe en el contexto registral ${ }^{47}$, lo que obliga a definir su puntual

47 Sobre el principio de buena fe en el ámbito del Derecho civil y, particularmente, en el contractual, consúltese WIEACKER, Franz, CARRO FERNÁNDEZ- VALMAYOR, José Luis y DIÉZ-PICAZO, Luis (1982). El principio general de la buena fe, Ed. Civitas, Madrid; GARCÍA AMIGO, Manuel (2000). "Consideraciones a la buena fe contractual", en Actualidad civil, Núm. 1, 2000, pp. 1-15; 0JEDA RODRíGUEZ, Nancy de la C. (2006). "Justicia contractual: principios de la buena fe y del justo equilibrio de las prestaciones en la contratación", en OJEDA RODRíGUEZ, Nancy de la C. (comp.) et al., Derecho de Contratos, Tomo 1 - Teoría general del contrato, Ed. Félix Varela, La Habana, pp. 21-56. Sobre la buena fe registral, vid. SÁNCHEZ JORDÁN, María Elena (20019). "Buena fe e información registral”, en GÉNOVA GALVÁN, Alberto y PI, Juan Romero (dirs.), MELERO BOSCH, Lourdes Verónica y NAVARRO FRÍAS, Irene (coords.) et al., Estudios jurídicos en homenaje al profesor Dr. D. Francisco Clavijo Hernández, Ed. Aranzadi-Thomson Reuters, Cizur Menor, pp. 373-400; JÉREZ DELGADO, Carmen (2005). La buena fe registral, Ed. Colegio de Registradores de la Propiedad, Mercantiles y de Bienes Muebles de España, Madrid; GOÑI RODRíGUEZ DE ALMEDIA, María (2005). "Buena fe en Derecho Inmobiliario Registral", en Revista Crítica de Derecho Inmobiliario, Año LXXXI, Núm. 687, pp. 292-296; ESTER BUTRAGUEÑO, Pedro (1996) “La protección registral al tercer adquirente y el requisito de la buena fe", en DIEZ-PICAZO GIMÉNEZ, Ignacio y MARTÍNEZ-SIMANCAS SÁNCHEZ, Julián (coords.) et al., Estudios sobre derecho procesal, Vol. 2 - Ejecución forzosa. Medidas cautelares, Ed. Banco Central Hispanoamericano, Madrid, 
significado en este escenario, su alcance y el momento en que debe ser estimada para el logro de la protección.

De la revisión de las sentencias del alto foro se constata la falta de nitidez acerca del concepto de buena fe en sede registral, como consecuencia de la invocación del principio regulado en el artículo 6 del CC que opera para todas las relaciones jurídicas civiles y familiares, pero se concreta de manera distinta, según el ámbito de que se trate. La alegación de este principio general no resulta ociosa, pues a diferencia -por ejemplo- del ordenamiento español, el artículo 34 de la LHU no establece de manera expresa este requisito de protección, como tampoco lo hace la Ley Hipotecaria española de 1861, de la que abreva la cubana. La incorporación de la buena fe en el contexto español se debe a posteriores reformas implementadas en el siglo $\mathrm{XX}$, cuando Cuba deja de ser territorio de Ultramar.

Del examen de las sentencias se deduce la carencia de una construcción medianamente acabada de la buena fe exigible al tercero adquirente, así como de su preciso alcance y momento de apreciación, que redunda en falta de certidumbre de los justiciables en cuanto al resultado del proceso. Llama la atención la sentencia del TSP Núm. 212, de 30 de agosto de 2019, que en su segundo Considerando relaciona la buena fe exigible a los terceros adquirentes con su dimensión general -como principio del Derecho- y no circunscrita al contexto registral, a pesar de que el inmueble transmitido se encontraba inscrito en el Registro de la Propiedad ${ }^{48}$. Más próxima la buena fe registral, la sentencia

pp. 1457-1490; ESCOBAR ROZAS, Freddy (2015). "La muerte de la buena fe registral", en THEMIS: Revista de Derecho, Núm. 67, pp. 321-332.

48 Dispone el tribunal actuante que "(...) sentado que la acción de nulidad es ejercitable en cualquier momento por quien ostente interés legítimo, su despliegue tiene por límite causar daño a otro, lo que en el pleito sería inevitable para los sujetos que en tan extenso tracto han intervenido de buena fe en la confianza de que los actos y contratos celebrados son indiscutiblemente válidos, sustento que debió tomar en cuenta el órgano juzgador para equilibrar los intereses de los contendientes, los cuales, en toda circunstancia deben ponderarse de conformidad con los cánones de buena fe, lealtad y corrección debida de las conductas impropias, en aras de que los derechos subjetivos objeto de tutela judicial, no se transformen 
Núm. 1062, de 29 de diciembre de 2017, aunque sostiene en el artículo 6 del CC el fallo favorable al tercero adquirente -en este caso mediante contrato de permuta-, deja sentado que este no tiene forma de conocer las causas de invalidez del negocio antecedente, al momento de la celebración del contrato por el cual adquiere ${ }^{49}$.

Desconcierta, por otra parte, la sentencia del TSP Núm. 385 de 29 de junio de 2019, que impone a los terceros adquirente una suerte de obligación de actuar diligentemente en función de conocer las causas de ineficacia del negocio anterior al que pretenden formalizar, al tiempo que ignora el hecho de que el Registro no haya dado noticias sobre tal particular ${ }^{50}$. De similar talante, la sentencia Núm. 452 de 16 de julio de $2019^{51}$ hace

en arbitrarios, frente a la preeminencia del no abuso del derecho y de la seguridad jurídica como básica premisa de las relaciones de derecho entre las personas naturales, principio que devendría socavado de proteger el ejercicio tardío que en jurisdicción civil se ha invocado contra los terceros adquirentes de buena fe (...)".

49 Por ello, el órgano juzgador, motiva la segunda sentencia, en su único Considerando, de la siguiente manera: “(...) se encuentra acreditado que en el acto jurídico de permuta cuya nulidad se pretende, funciona a favor de la demandada la presunción de actuación de buena fe, que pondera el artículo seis del Código civil, pues como ya se expresó al momento de materializarse no existía impedimento legal alguno que impidiera su realización, y solo, en virtud de actuación posterior de la que acciona es que perdió eficacia la titularidad que en exclusiva gozaba YLH, lo que no puede afectar a quien ha actuado con plena conciencia de que no existía impedimento alguno en su materialización y que deviene en un tercero de buena fe en la relación jurídica, teniendo virtualidad el derecho reconocido a la actora en el inmueble adquirido por la impugnada permuta, por lo que acogiendo la excepción perentoria sobre adquisición a título oneroso y de buena fe opuesta por la demandada".

50 Así, invoca en su segundo Considerando: "( ...) en modo alguno cabe apreciar en quienes recurren la condición de adquirentes de buena fe merecedores de la protección judicial que interesan, dados los elementos de hecho contenidos en la sentencia cuestionada, referidos a la espuria adquisición originaria de los controvertidos inmuebles que obligaba a los interesados en su adquisición por compraventa a un mínimo de actuar diligente que no cumplimentaron, ni basta la aducida inexistencia de nota preventiva registral en los asientos de inscripción registral a tales efectos". Recurso de Casación Civil radicado al expediente Núm. 347 de 2019, interpuesto contra la Sentencia Núm. 83, de 12 de junio de 2018, dictada por la Sala Segunda de lo Civil y de lo Administrativo del Tribunal Provincial Popular de La Habana, en el proceso civil ordinario Núm. 249 de dos 2018 sobre Nulidad de Contratos de Compraventa de Viviendas.

51 Recurso de Casación radicado al expediente Núm. 465 de 2019, interpuesto contra la Sentencia Núm. 9, de 31 de enero de 2019, dictada por la Sala Primera de lo Civil y de lo 
notar en su tercer Considerando que: “(...) en este específico caso, quedó destruida la buena fe alegada, al comprobarse las múltiples transiciones que en relación al bien acontecieron en un corto periodo de tiempo sin que sus adquirentes adoptaran al respecto una actitud diligente, lo que impide la protección exigida (...)". Asimismo, en las sentencias de la máxima judicatura Núm. 234, de 20 de abril de $2017^{52}$, y Núm. 680, de 31 de agosto de $2018^{53}$, desacertadamente, el juzgador considera que debe mediar cumplida demostración de que el tercero adquirente actúa de modo cuidadoso y diligente, lo que da al traste con la presunción de buena fe que legalmente les beneficia.

De ahí que varios pronunciamientos apunten hacia la exigencia de elevados estándares de diligencia al tercero adquirente, con lo cual se visualiza cierta inclinación hacia la apreciación de la buena fe ética y no la buena fe psicológica ${ }^{54}$; cuestión que

Administrativo del Tribunal Provincial Popular de La Habana, en el proceso civil ordinario Núm. 210 de 2018, sobre Nulidad de acto jurídico.

52 En su primer Considerando precisa que: "(...) atendible la buena fe que se invoque en favor del adquirente, debe mediar cumplida demostración de que este actuó de modo cuidadoso y obró con diligencia, consultando los antecedentes que constituyen el tracto del bien previo a la adquisición (...)". Recurso de Casación Civil radicado al expediente Núm. 88 de 2017, interpuesto contra la Sentencia Núm. 284 de 2 de noviembre de 2016, dictada por la Sala Primera de lo Civil y de lo Administrativo del Tribunal Provincial Popular de La Habana, en el proceso civil ordinario Núm. 102 de 2016, sobre Nulidad de permuta contenida en documento notarial.

53 El primer Considerando de esta resolución infiere: “( ...) que no basta la mera alegación por la casacionista de la actuación de buena fe, pues para que resultara atendible en favor de la adquirente, debió justificar que actuó de modo cuidadoso y diligente, consultando los antecedentes que componen el tracto histórico el bien antes de la adquisición, además de que no pudo demostrar un proceder impoluto e irreprochable como sería de esperar por quien alega la condición de adquirente de buena fe, que se contradice, de acuerdo a las máximas de experiencia comunes, con la declaración como precio de la adquisición de espaciosa y confortable propiedad inmobiliaria en municipio céntrico de la capital del país la irrisoria suma de setenta mil pesos moneda nacional (...)". Recurso de Casación Civil radicado al expediente Núm. 558 de 2018, interpuesto contra la Sentencia Núm. 28, de 19 de marzo de 2018, dictada por la Sala Primera de lo Civil y de lo Administrativo del Tribunal Provincial Popular de La Habana, en el proceso civil ordinario Núm. 254 de 2017, sobre Nulidad de actos jurídicos contenidos en documentos notariales.

54 La buena fe ética exige del tercero un comportamiento moralmente adecuado, para no infringir los derechos preexistentes; actuación que precisa el conocimiento de la realidad 
puede convertirse en un arma de doble filo si concurren otros presupuestos que favorecen la tuición del tercero adquirente. En cuanto al momento de apreciación, sin embargo, las valoraciones son omisas.

Otro signo de alarma constituye la peculiar interpretación del alto foro acerca de la presunción de buena fe, sinuoso una vez más. Por ejemplo, la resolución judicial Núm. 463, de 18 de julio de 2019, casa la sentencia de instancia sobre el argumento de que "(...) la casacionista se erige como un tercero que ha actuado de buena fe, principio general del derecho que

y extravasa la información publicada por el sistema tabular. Esta tesis que exige al tercero una especial diligencia, la sustentan VALLET DE GOYTISOLO, Juan B. (1962). "La buena fe, la inscripción y la posesión en la mecánica de la fe pública", en Estudio de derechos de cosas y garantías reales, Ed. Colección Nereo, Barcelona, p. 220; ESPEJO LERDO DE TEJADA, Manuel (2007). "La buena fe requerida por el adquirente en remate a debitore non domino: comentario a la STS de 5 de marzo de 2007", en Revista Aranzadi de Derecho Patrimonial, Núm. 19, p. 412; GORDILLO CAÑAS, Antonio (2006). “El principio de buena fe registral (I)", en Anuario de Derecho Civil, Vol. 59, Núm. 2, Madrid, 2006, p. 509. Por su parte, la buena fe psicológica implica el convencimiento de la exactitud del contenido del Registro, de que el transmitente es el verdadero y único titular registral del derecho que se pretende adquirir y, por tanto, de su legitimación para disponer; es actuar confiado en que no existen más limitaciones que las que dimanan del asiento de inscripción y constan en la correspondiente certificación. Suscriben esta tesis, MIQUEL GONZÁLEZ, José María (1990) "La buena fe y su concreción en el ámbito del Derecho Civil", en Anales de la Academia Matritense del Notariado, Núm. XXI, p. 19; GARCÍA GARCÍA, José Manuel (1999). "Artículo 34", en ALBALADEJO, Manuel (dir.) et al., Comentarios al Código Civil y Compilaciones Forales, Tomo VII, Vol. 4: Artículos 18 a 41 de la Ley Hipotecaria, Ed. Edersa, Madrid, pp. 479-481; ROCA SASTRE, Ramón Ma , ROCA SASTRE NUCUNILL, Luis y BERNA I XIRGO, Joan (2008). Derecho Hipotecario, Tomo II, Vol. 2, ga edición, Ed. Bosch, Barcelona, p. 197; MÉNDEZ GONZÁLEZ, Fernando P. (2015). "37. Comentario a la Sentencia del Tribunal Supremo de 12 de enero de 2015 (271/2015). Desafectación tácita. La diligencia básica exigible para la buena fe del art. 34 LH", en YZOUIERDO TOLSADA, Mariano (dir.) et al., Comentario a las Sentencias de Unificación de Doctrina (Civil y Mercantil), Vol. 7: 2015, Eds. Dykinson-AEBOE, Madrid, 2016, pp. 583-613, disponible en https://www.boe.es/biblioteca_ juridica/comentarios_sentencias_unificacion_doctrina_civil_y_mercantil/abrir_pdf. php?id=COM-D-201537_Comentarios_a_las_Sentencias_de_Unificacion_de_-Doctrina_ Civil_y_Mercantil__Desafectaci\%C3\%B3n_t\%C3\%A1cita._La_diligencia_b\%C3\%A1 sica_ exigible_para_la_buena_fe_del_art._34_LH, consultado el 23 de julio de 2020, 4:08 p.m.; y, del propio autor, "La "buena fe» del art. 34 de la ley hipotecaria. Una revisión crítica de la posición dominante en la doctrina y en la jurisprudencia", en Revista Jurídica de Catalunya, Núm. 1, 2018, pp. 9-40. 
presumible, según lo que preconiza el artículo seis del Código Civil, al no ser desvirtuado alcanza a la inconforme (...)"55. Igualmente, con acierto, la sentencia del TSP Núm. 601 de 20 de agosto de 2019, en su primer Considerando motiva, que: "(...) las pruebas referenciadas por la mentada no alcanzan para desvirtuar la actuación de buena fe de los abora titulares del recinto al realizar el negocio que los erigió como tal, adquirentes protegidos por la sala sentenciadora con apoyo en la evaluación de la información aflorada de las diligencias de probanza ejecutadas (...)", lo que manifiesta la correcta observancia de dicha presunción.

Sin embargo, son las citadas sentencias Núm. 234, de 20 de abril de 2017, y Núm. 680, de 31 de agosto de 2018, así como la dictada el 31 de enero de $2019^{56}$, las que desnaturalizan esta presunción destruible a instancia de parte interesada. La última de ellas, es exponente de la extralimitación en el alcance de la buena fe y de la alteración de la regla establecida en el artículo 6 del CC. Según la síntesis del razonamiento contenido en su segundo Considerando ${ }^{57}$, es el tercero adquirente quien

\footnotetext{
55 Este argumento se refuerza en el único Considerando de la segunda sentencia, cuando se expresa: "( ...) consta acreditado que en el acto jurídico de compraventa, cuya nulidad se pretende en el presente, funciona la presunción de actuación de buena fe en favor de la adquirente, regulado en el artículo seis del Código Civil, pues al momento de materializarse no existía impedimento legal para limitarse en su realización, ya que fue en virtud de actuación posterior de quien acciona que perdió eficacia la titularidad disfrutada en exclusiva por el vendedor, situación que no puede afectar a quien intervino con plena conciencia de que no existía obstáculo para concertar la relación jurídica en examen (...)".

56 Recurso de Casación Civil radicado al expediente Núm. 765 de 2018, interpuesto contra la Sentencia Núm. 82, de 12 de junio de 2018, dictada por la Sala Segunda de lo Civil y de lo Administrativo del Tribunal Provincial Popular de La Habana, en el proceso civil ordinario Núm. 282 de 2017, sobre Nulidad de actos jurídicos.

57 Segundo Considerando: "(...) en el caso, concurren circunstancias objetivas que indican que la inconforme no debe ser beneficiada con la especial protección que invoca (...) salta a la vista la irrefutable proximidad en el tiempo de disposiciones administrativas y actos notariados e inscritos en el Registro de la Propiedad sucesivamente y en breve plazo, a pesar de la variedad y complejidad de los trámites que genera la ubicación geográfica del bien controvertido (...); lo que frustra la tesis de la quejosa, pues no basta la mera alegación de la actuación de buena fe, pues se trata de presunción destruible por prueba en contrario,
} 
debe probar su buena fe, no solo imponiéndole un estándar de diligencia elevadísimo, sino afectándola con cuestiones puramente negociales, como lo es la determinación del precio de la venta ${ }^{58}$; cuando en puridad, quien debe desvirtuar la buena fe es la persona que alega una actuación en contrario. Por ello, no es el tercero quien tiene que probar su desconocimiento o su conducta dirigida a conocer determinada realidad que no le consta a partir del Registro, pues el artículo 6 del CC le ampara.

Luego, la concreción de tales aspectos y la asunción de criterios homogéneos que puedan valorarse caso a caso en función de la efectiva impartición de justicia, deviene cuestión medular para la judicatura cubana. En su virtud, no se descarta del todo la elección de la concepción ética de la buena fe -con los ajustes y la prudencia convenientes-, teniendo en cuenta las vicisitudes del tráfico inmobiliario nacional -aun resentido por la etapa anterior al Decreto Ley Núm. 288/2011 y la decadencia temporal del Registro de la Propiedad- y los temores -fundados o no- de que se puede estar cometiendo un acto de injusticia con el titular civil cuando se inmunice la adquisición de una persona, por el solo hecho de haber confiado en este medio para adquirir y asegurar su derecho, ignorando que lo publicado es inexacto. Pero, ¿acaso no sería injusto con el adquirente imponerle la carga de comprobar -por él o a costa de su patrimonio- la situación real de la finca que pretende adquirir para resultar privilegiado, cuando necesariamente tiene que

como en el caso acontece, para que resultara atendible en favor de la adquirente, tenía que tener buena fe, y justificarlo con elementos concretos, sin dejar dudas acerca de un quehacer medianamente diligente, como sería el agotar la consulta de los antecedentes que componen el tracto histórico del bien antes de la adquisición, más cuando la casacionista no pudo demostrar un proceder probo como sería de esperar por quien alega la condición de adquirente de buena fe, que se contradice, de acuerdo a las máximas de experiencia comunes, con la declaración como precio de la adquisición de espaciosa y confortable propiedad inmobiliaria en municipio céntrico de la capital del país de la irrisoria suma de novecientos sesenta mil pesos moneda nacional (...)".

58 Cuando la buena fe registral debe centrarse únicamente en el desconocimiento de la inexactitud registral, esto es, en la no correspondencia entre quien figura como dueño a través del Registro y quien conforme a las reglas del Derecho Civil estricto es el propietario. 
acreditarse que el derecho del transmitente está inscrito dado el carácter obligatorio de la inscripción?

La exigencia de cierta diligencia en el adquirente a fin de contrastar la información registral con la realidad extrarregistral, no puede traducirse en absoluto desmedro de la institución jurídica creada para asegurar los derechos reales y conceder, a quien confía e inscribe, determinado grado de protección. La visión integral del sistema cubano de transmisión y adquisición de este tipo de derechos en relación con la naturaleza del Registro de la Propiedad -cuyos asientos producen efectos jurídicos de cara al titular inscrito y a los terceros, entre ellos, la fe pública registral-, apoyado en un notariado de elevado rigor técnico, integrado por funcionarios públicos que a la vez son profesionales del Derecho, exige -en criterio propio- asumir una postura congruente con la buena fe psicológica.

El otro extremo solo se justifica en casos muy concretos donde se resiente la presunción de buena fe, pero no se desvirtúe del todo, o sea, la contraparte logra sembrar en el juzgador la duda razonable acerca del conocimiento de la inexactitud registral por parte del adquirente, sin haber podido demostrar este hecho de manera contundente. Ello amerita una valoración por parte del tribunal actuante de la conducta desplegada por el tercero y, por tanto, de su diligencia y comportamiento ético, pero -se insistesolo cuando a su prudente arbitrio sea preciso para clarificar estas dudas, imponiéndole, eso sí, un estándar de diligencia que se corresponda con sus posibilidades reales, las circunstancias concurrentes y contemple, asimismo, su error excusable.

Tendencia núm. 5: Supeditación de la protección del tercero a la falta de diligencia, el abuso del derecho o la responsabilidad del titular civil

No figuran estos entre los requisitos de la protección preferente a favor del tercero adquirente. La conducta del titular civil puede ser tomada en cuenta para definir la regla de responsabilidad mediante la cual ha de quedar protegido su derecho, 
pero no para determinar la atribución de la regla de propiedad al tercero. De ser así, se trata de un despropósito del sistema, el cual ontológicamente se establece en función de proteger la seguridad del tráfico y jurídica en general, y no de penalizar o sancionar a quien, de cierta forma, ha propiciado la apariencia jurídica que luego ha sido aprovechada por los terceros.

De ahí que valoraciones como la inacción sostenida del titular, como expresión del abuso del derecho, o su negligencia, o incluso la falta de diligencia por no inscribir oportunamente su titularidad, devienen superfluos elementos de valor para determinar la solución jurisdiccional; como lo hace la sentencia del TSP Núm. 61, de 10 de febrero de 202059, al estimar en su primer Considerando que "(...) ha actuado la recurrente con la debida diligencia en el reconocimiento y reclamación de sus derechos como cónyuge y cotitular del inmueble, circunstancia que impide dispensar a quienes se proclaman adquirentes de buena fe, el amparo que reclaman, que tendría que pasar por la conducta abusiva de la accionante". En consecuencia, los elementos identificados -u otros concordantes- no deben ser tomados como contrapeso de la tutela privilegiada del tercero adquirente, la que ha de dispensarse -en todo caso- pasando por alto la imputabilidad de la conducta del titular civil.

\section{Tendencia núm. 6: Ponderación del derecho a la herencia y el derecho del tercero adquirente de la vivienda}

Este particular conflicto se somete a ciertas reglas dentro de la propia dinámica de la fe pública registral, toda vez que no se trata del clásico supuesto en que la contraparte es titular del derecho de propiedad, sino que actúa en razón del derecho hereditario violado por el transferente, lo que le ha impedido

\footnotetext{
59 Recurso de Casación Civil radicado al expediente Núm. 974 de 2019, interpuesto contra la Sentencia Núm. 38, de 31 de julio de 2019, dictada por la Sala de lo Civil, de lo Administrativo, de lo Laboral y de lo Económico del Tribunal Provincial Popular de Artemisa, radicado al proceso civil ordinario Núm. 9 de 2019, sobre Nulidad de Contratos de Permuta, Compraventa y Donación de Viviendas.
} 
convertirse en propietario del bien, ya sea de manera conjunta o exclusiva. Por consiguiente, pueden darse dos supuestos: la actuación de un heredero aparente, adjudicatario del inmueble, cuyo título causal de adquisición constituye un acto de naturaleza mortis causa que ha cobrado virtualidad con soslayo de otro heredero preferente, o de un heredero-transferente que vulnera el derecho de su coheredero. En este último caso, la apariencia tiene el matiz de que, en puridad, corresponde cierta legitimación al transferente, quien se extralimita en su derecho y se envuelve de la condición de único heredero en perjuicio del coheredero excluido.

Como se puede deducir, no se enmarca, exactamente, en los tradicionales supuestos que configuran la aplicación de la fe pública registral a favor del tercero adquirente; pero ello no indica que este efecto registral sea absolutamente inaplicable a situaciones como la narrada, donde opera una transmisión derivativa por parte del heredero o coheredero aparente, cuya adquisición misma resulta susceptible de impugnación por diversas causales de ineficacia.

Lo que sucede es que suele establecerse, justamente, por la inseguridad que genera los títulos causales de naturaleza sucesoria, de carácter voluntario, un plazo de suspensión de los efectos de la fe pública registral. Así lo hace el artículo 28 de la LH española y el artículo 23, segundo párrafo de la $\mathrm{LHU}^{60}$. Suspender este efecto por un período de tiempo razonable -dos años después de la muerte del causante, lo parece- tiene gran significación práctica. Durante ese lapso puede el heredero voluntario real accionar y obtener el reconocimiento del derecho vulnerado, así como la declaración de ineficacia de la adjudicación si esta ha tenido lugar, sin menoscabo de los intereses de terceras personas. De modo que, quien adquiera del adjudicatario

\footnotetext{
60 Artículo 23, segundo párrafo: La inscripción de los bienes inmuebles y derechos reales adquiridos por herencia o legado no perjudicará a tercero, si no hubiesen transcurrido cinco años desde la fecha de la misma. Exceptúense los casos de herencia testada o intestada, mejora y legado, cuando recaiga en herederos forzosos.
} 
legitimado por el Registro, en plena vigencia de dicho plazo, corre el riesgo de sufrir las consecuencias nocivas de la impugnación del heredero "preterido", toda vez que el manto cobertor de la fe pública registral solo le cubre una vez que haya vencido.

Respecto a este particular conflicto relacionado con la aplicación de la fe pública registral, el estudio de sentencias realizado revela que ninguno de los fallos se funda en los preceptos de la LHU, que debe interpretarse evolutivamente en virtud de que el CC cubano de 1987 no reconoce, por ejemplo, los llamados herederos forzosos, sino los herederos especialmente protegidos, quienes deben reunir especiales requisitos ( $c f r$. artículo 493, apartado 1). Las peculiaridades que esta variante introduce a la especial tutela a favor de estos sujetos, en razón de la fe pública registral, requiere un abordaje que escapa del objeto del presente artículo.

Prevalecen a favor de los herederos o coherederos vulnerados, dicho sea de paso, generalmente por un título sucesorio abintestato, interpretaciones relacionadas con el carácter preferente del derecho a la herencia o con el efecto dominó que provoca la nulidad del acto de adjudicación -en desmedro de herederos que modifican o anulan este título causal- sobre los actos o contratos celebrados con posterioridad. Así, la sentencia del TSP Núm. 335, de 13 de mayo de $2016^{61}$, acoge en su primer Considerando el recurso interpuesto, al expresar que "(...) es

61 La segunda sentencia enfatiza: "queda debidamente demostrada la viabilidad de la pretensión deducida, ante la firmeza de resolución judicial que elimina los efectos jurídicos del acto de adjudicación hereditaria que sobre el bien objeto del conflicto realizara el no recurrente para adquirir la titularidad domínica que viabilizó su ulterior enajenación mediante el impugnado contrato, condicionada por la modificación judicial del título sucesorio que en exclusiva le confirió indebidamente el estatus de único heredero intestado de la titular anterior, de suerte que la carencia del carácter de propietario que requieren los contratos traslativos del dominio, específicamente a cargo del vendedor en el de compraventa, (. . .) deviene procedente estimar la demanda en examen". Recurso de Casación Civil radicado al expediente Núm. 173 de 2016, interpuesto contra la Sentencia Núm. 328 de 18 de noviembre de 2015, dictada por la Sala Primera de lo Civil y de lo Administrativo del Tribunal Provincial Popular de La Habana, en el proceso civil ordinario Núm. 388 de 2015, sobre nulidad de contrato de contrato de compraventa de vivienda. 
lo cierto que en el específico supuesto de hecho sujeto a juzgamiento en el proceso en examen, el acto de adjudicación bereditaria carece de efectos por la firmeza del resultado judicial nulificante alcanzado previamente, de suerte que ante la carencia del título de dominio que avale la transmisión objeto del control de los jueces, resulta adecuado y además pertinente el cauce escogido para privar de efectos al último de los actos que lesiona el patrimonio de quien recurre (...)". Luego, el tercero adquirente queda desprotegido.

\section{Tendencia núm. 7: Vía tuitiva alternativa atribuible al ter- cero adquirente}

Pocas resoluciones se ocupan de establecer, ante la pérdida del derecho de propiedad adquirido por el tercero mediante compraventa, la vía de tuición que queda expedita para este sujeto. Recientes razonamientos apuntan hacia el reconocimiento del saneamiento por evicción como vía alternativa de protección. Así lo hace la mentada sentencia Núm. 127 de 18 de marzo de 2019, cuando expresa en su segundo Considerando: "(...) salvo aquella a que se refiere el artículo trescientos cuarenta y uno y siguientes, del Código Civil, de manera que, en tal supuesto, resulta atinada la aplicación de las normas cuestionadas". Por otro lado, la reciente sentencia del TSP Núm. 61 de 10 de febrero de 2020, dispone de manera expresa, en el primer Considerando de la segunda sentencia que: "(...) actuando con evidente mala fe e ignorando la situación en que inmiscuía a los terceros adquirentes que desconocían del vicio que padecía la titularidad de la vivienda, a los que no es atinado brindar protección en el presente, salvo la de saneamiento por evicción que pudieran reclamar en proceso distinto (...)".

\section{Tendencia núm. 8: Línea de solución judicial de estos con- flictos y la posible jurisprudencia}

La ausencia de una línea de solución judicial uniforme de los asuntos relativos a los terceros adquirentes, que pueda ser tomada en cuenta por los tribunales inferiores en la impartición 
de justicia, conduce a la inexistencia de jurisprudencia al respecto. Se aprecian soluciones casuísticas que no toman en cuenta principios y presupuestos que pueden estar presentes y ser aplicables a casos similares. Además, los dictados que privilegian al tercero, suelen ser escasos, aislados y de fundamentación variable, con soslayo de disposiciones jurídicas idóneas que se encuentran vigentes, lo que configura, a juicio propio, una infracción por falta de aplicación de normas que tienen una eficacia potencial dentro del ordenamiento registral, especialmente, el artículo 34 de la LHU. Asimismo, se produce una interpretación errónea de este precepto en relación con el artículo 33, con reflejo en la aplicación indebida de normas que no imperan cuando se trata de una propiedad inmobiliaria inscrita en el Registro de la Propiedad, cuyos efectos son supletorios. Todo ello atenta, directamente, contra la previsibilidad de las soluciones judiciales y la seguridad jurídica, en sus variantes pública y privada.

El valor de la inscripción, la tutela jurídica que ha de dispensársele al titular inscrito -el tercero adquirente que se inscribe es uno de ellos- por el hecho de haber confiado en el mecanismo público que se encarga de dar publicidad y asegurar, en este caso, al derecho de propiedad, no se acoge ni se declara en los fallos examinados. La magistratura cubana, a diferencia de algunos dictados provinciales donde se reconoce este efectoprincipio, cuida de no fallar ningún asunto -a pesar de que los abogados alegan la aplicación del artículo 34 LHU- sobre la base del efecto principal que ha de producir un Registro de la Propiedad como el cubano. Por tal razón, obvio resulta que, tras casi una década de vigencia del Decreto Ley Núm. 288/2011, no se ha logrado una configuración jurisdiccional acabada en torno a la protección de los terceros adquirentes de viviendas en Cuba.

\section{Algunas pautas de actuación jurisdiccional que propenden a la protección efectiva}

La protección a los terceros adquirentes de viviendas por la que se aboga, descansa en la atribución de una regla de 
propiedad que asegure el derecho real adquirido mediante la celebración del contrato de compraventa. Las peculiares características del contexto cubano actual -sobre todo en los órdenes social y económico-, unido a los vaivenes en la operatividad del Registro de la Propiedad y en la autonomía de la voluntad contractual con incidencia en el tráfico inmobiliario, han afectado, en la práctica, la inclinación de la balanza hacia la esfera jurídica del tercero adquirente; tal es así que los comentarios anteriores demuestran el desconocimiento de la aplicación preferente del régimen de publicidad registral, así como la eficacia del aseguramiento que de él emana. Pero su protección no resulta imposible, debe ganarse en convencimiento de que los postulados sustantivos que ordenan el sistema registral gozan de plena vigencia y aptitud para regir la resolución de estos conflictos en las circunstancias actuales.

De modo que el andamiaje institucional del país y su normativa -aun con insuficiencias- ofrece una protección a los terceros adquirentes que toma como punto de partida el Registro de la Propiedad. Retocado en cuanto a su organización y funcionamiento, esta institución goza de vocación protectora con asidero en el artículo 34 de la LHU; empero, hacerla efectiva precisa de la imprescindible tutela judicial. El paso del tiempo no exige, en esencia, una interpretación evolutiva de esta norma específica que atempere aplicaciones incongruentes a las condiciones reales del tráfico cubano o las que se deducen del análisis sistemático del ordenamiento nacional, sino todo lo contrario; se demanda su aplicación tal cual, sin más reservas que el riguroso cumplimiento de los presupuestos y requisitos de protección. Respecto a la exigencia de la buena fe del adquirente, apreciable al momento de perfección del contrato que genera el título inscribible, al no encontrarse regulada expresamente en el artículo 34 de la LHU -en franca sintonía con el desarrollo doctrinal del estatuto tuitivo de los terceros adquirentes-, ha de conectarse con el artículo 6 del CC, en virtud del alcance supletorio de este cuerpo legal. 
Lo indicado anteriormente garantiza una solución inmediata a la problemática que ha sido centro de atención, ya que permite en el corto plazo brindar protección a los terceros adquirentes de viviendas sobre la base de una norma jurídica vigente, en cuya funcionalidad se ha hecho hincapié. No se trata de una solución caprichosa ni forzada, sino respetuosa de lo establecido legalmente, aunque provenga de un momento histórico pasado que ahora precisa ser retomado, en defecto de una regulación moderna que despeje las dudas sobre su aplicación. Esta solución es, además, la más eficiente, porque ofrece mayores ventajas a menores costes, de cara a la efectividad del resultado del proceso. Téngase en cuenta que quien tiene el inmueble en su poder es el tercero adquirente, el cual actúa conforme a las exigencias legales y del tráfico -verifica registralmente la titularidad de su transmitente y confía en la información brindada, desconociendo la presencia de causas que puedan poner en peligro su adquisición-, por lo que, conminarlo a restituir el bien no resulta de sencilla realización, ya que puede retrasar su entrega o efectuarla de modo perjuicioso.

Mayor complejidad presenta el escenario en que una cadena de transmisiones -integrada por al menos dos compraventas sucesivas al título declarado ineficaz- se resquebraja; pues la plena satisfacción del titular civil, protegido por la atribución judicial de una regla de propiedad, depende de la colaboración del tercero adquirente que posee la vivienda, quien no tiene porqué conocer al transmitente que ha actuado a non domino, al no relacionarse contractualmente con él. En estos casos, garantizar la protección efectiva del derecho de propiedad del titular civil, así como el ejercicio de acciones personales por parte del tercero adquirente contra el transferente a non domino, resulta tarea espinosa, pues se pone en tela de juicio la eficiencia de la tutela jurisdiccional al tomar como baremo la seguridad jurídica. Resulta más seguro mantener en su posición al último que ha adquirido onerosamente y de buena fe -bajo la apariencia jurídica que del sistema registral dimana y en 
razón del valor de su inscripción- y, en consecuencia, reparar económicamente al titular civil; quien, en razón de la eventual relación que le une al transmitente, se encuentra en mejor condición que aquel -sobre todo, en transferencias sucesivas- para exigirle responsabilidad.

Por tales razones, resulta conveniente, establecer determinadas pautas de actuación que, a modo de guía, puedan ser empleadas por los jueces en la impartición de justicia. De tal suerte, estos conflictos que se caracterizan por su alto grado de complejidad técnica y elevada sensibilidad económica y social pueden ser dirimidos -en las condiciones normativas actuales- con mayor eficiencia; al garantizar un mayor grado de uniformidad, equidad y seguridad jurídica. Se proponen, en consecuencia, las siguientes líneas de razonamiento coherente que puede considerar el juzgador para tomar en consideración el interés jurídicamente relevante en el conflicto de derechos.

$\left.1^{a}\right)$ Determinación de la condición de tercero adquirente. La comprobación de si el sujeto que alega su condición de tercero adquirente ciertamente lo es, deviene cuestión básica pero imprescindible para garantizar una correcta aplicación del Derecho. Ello requiere, en consecuencia, la adecuación de la situación fáctica concreta al concepto de tercero adquirente de inmuebles, lo que hace posible su identificación.

$2^{\text {a }) ~ E v a l u a c i o ́ n ~ d e ~ l o s ~ p r e s u p u e s t o s ~ d e ~ p r o t e c c i o ́ n . ~ R e s u l t a ~}$ absolutamente necesario el deliberado control de la concurrencia de los presupuestos para proteger al tercero adquirente mediante la fe pública registral. Primero, que su negocio adquisitivo cuenta con los elementos de validez requeridos legalmente ( $c f r$. artículo 33 LHU); y segundo, la presencia de inexactitud registral. Ello favorece el rechazo de situaciones que no ameritan la tutela preferente si no se cumplen tales presupuestos y, en caso favorable, abre paso a la evaluación del resto de las circunstancias. La invalidez de la propia adquisición obstruye toda posibilidad de proteger, incluso, mediante una regla de responsabilidad al tercero adquirente. Sin embargo, 
la falta de inexactitud registral, como consecuencia de la no inscripción del acto transmisivo-adquisitivo en el Registro de la Propiedad por parte de este sujeto, conduce a la valoración de vías alternativas de tuición (en el mismo u otro proceso), si ha actuado conforme a determinados cánones que ameriten la atribución de una regla de responsabilidad.

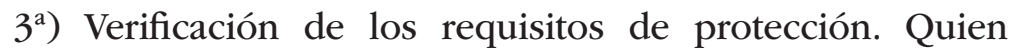
resuelve debe comprobar la materialización de los requisitos de protección en el tercero adquirente: que el transferente haya inscrito su negocio adquisitivo; que el tercero haya inscrito su adquisición; que esta sea onerosa; y que se constate la buena fe registral. Este último, demanda del tribunal toda su agudeza, pues ha de garantizar el respeto al carácter presuntivo de la buena fe, destruible mediante hechos probados por la contraparte. En cuanto a su alcance, ha de inclinarse por la concepción de la buena fe psicológica; admitiéndose la buena fe ética como fórmula para valorar -con prudencia- el interés defendible y exclusivamente en aquellos casos en que el juzgador albergue duda razonable. El momento de su apreciación es el de la autorización del contrato traslativo, sin que deba extenderse hasta la solicitud y práctica de la inscripción.

$4^{\mathrm{a}}$ ) Aplicación del artículo 34 LHU. La confirmación de los requisitos mencionados permite identificar al tercero hipotecario, solo así se procede a la aplicación del precepto indicado para proteger su derecho real mediante una regla de propiedad, lo que tributa no solo al cumplimiento de la legalidad y la consagración de la justicia y equidad, sino también a la consecución de una solución eficiente del conflicto, que asegura la efectividad del derecho adquirido y la seguridad jurídica.

$5^{a}$ ) Reconocimiento de la regla de responsabilidad para el titular civil. La vía tuitiva disponible para el titular civil cuando todo apunte hacia la aplicación del artículo 34, constituye un deber ineludible del tribunal actuante en función de la genuina impartición de justicia; aunque la atribución de la regla de responsabilidad se concrete posteriormente a través del ejercicio 
de la acción personal más adecuada, e incluso, mediante la vía penal que pudiera quedar expedita, según los hechos probados.

$\left.6^{a}\right)$ Fundamentación del fallo como un principio abarcador de protección. Para fundamentar el fallo debe tomar en cuenta la premisa de que la salvaguarda a los terceros adquirentes no ha de conseguirse casuísticamente, sino que requiere la aplicación de un principio abarcador de protección con razonamiento sobre la pertinencia de los presupuestos y requisitos en el caso concreto.

\section{Reflexión final}

Tras casi cuarenta años de eterno letargo en cuanto a la protección de los terceros adquirentes de viviendas en Cuba, imprescindible resulta encauzar las soluciones jurisdiccionales hacia la senda de la predictibilidad y la seguridad jurídica. Estos sujetos demandan en la actualidad la elucidación de una vía tuitiva que les garantice de manera efectiva el derecho de propiedad adquirido, el legítimo interés de conservarlo y de ser tenidos por titulares in rem. En este sentido, la judicatura cubana debe uniformar prácticas y argumentar sus fallos sobre la base del Derecho aplicable y los fundamentos técnicos que permiten sustentar las adquisiciones a non domino.

En definitiva, un fallo estimatorio de la protección a los terceros adquirentes potencia la realidad jurídica registral y la confianza que depositan en ella los terceros, al tiempo que fortalece la presencia y eficacia sustantiva del Registro, e incentiva a los particulares a inscribir y a utilizar el aseguramiento registral en función de realizar sus transacciones sobre bienes inmuebles, especialmente, viviendas de residencia permanente. En tanto, un fallo desestimatorio, si bien afianza la estabilidad de los derechos reales adquiridos conforme al Derecho Civil estricto, ofrece prevalencia a la realidad jurídica extrarregistral en desmedro de la registral, lo que implica -aunque no sea la intención- una importante obstaculización para que el Registro 
de la Propiedad cubano gane en eficacia sustantiva e impacto en la sociedad, lo que trae aparejada su desnaturalización. Esta última postura no es consecuente con el interés público de procurar la institucionalización del Estado cubano, ni consolidar su modelo de desarrollo económico y social a través de la equidad, la seguridad y la eficiencia, valores esenciales que han de regir la impartición de justicia. 